\title{
Host country network, industry experience, and international alliance formation: Evidence from the venture capital industry
}

Article · November 2015

DOI: 10.1016/j.jwb.2015.10.008

CITATION

1

2 authors:

\section{Jing Zhang}

Old Dominion University

23 PUBLICATIONS 460 CITATIONS

SEE PROFILE
READS

128

\section{Amir Pezeshkan}

University of Baltimore

16 PUBLICATIONS 69 CITATIONS

SEE PROFILE 


\title{
Host country network, industry experience, and international alliance formation: Evidence from the venture capital industry
}

\author{
Jing Zhang ${ }^{\mathrm{a}, *, 1}$, Amir Pezeshkan ${ }^{\mathrm{b}, 1}$ \\ a Management Department, Strome College of Business, Old Dominion University, 2038 Constant Hall, Norfolk, VA 23529, United States \\ ${ }^{\mathrm{b}}$ Department of Management and International Business, Merrick School of Business, University of Baltimore, Baltimore, MD 21201, United States
}

\section{A R T I C L E I N F O}

\section{Article history:}

Received 8 September 2014

Received in revised form 27 August 2015

Accepted 22 October 2015

Available online 15 November 2015

\section{Keywords:}

International alliance formation

Network centrality

Venture capital

Industry experience

Resource dependence theory

Social network theory

\begin{abstract}
A B S T R A C T
Integrating resource dependence and social network theories, we investigate how foreign firms' position in alliance network in host country influences their further allying with firms from the host and home countries. We introduce network centrality as a factor that influences two competing forces in alliance formation: willingness and attractiveness. Furthermore, we argue that foreign firms suffering from a low network centrality may find it easier to enhance their network position if they have industry experience. Our analysis of data on US venture capital firms' investment in China supports our theoretical framework. Theoretical and managerial implications of our findings are discussed.
\end{abstract}

(c) 2015 Elsevier Inc. All rights reserved.

\section{Introduction}

What determines foreign firms' alliance formation in the host country? As a primary theoretical perspective to understand interorganizational relationships (Barringer \& Harrison, 2000; Hillman, Withers, \& Collins, 2009; Oliver, 1990), resource dependence theory (RDT) has attributed alliance formation to underlying resource interdependence (e.g., Yan \& Gray, 1994); that is, since firms depend on each other's resources, they have both "inducement" and "opportunity" to form inter-firm links (Eisenhardt \& Schoonhoven, 1996).

Despite its foundational role in providing insights into interorganizational relationships, RDT has some limitations in explaining the nuances of alliance formation. First, although RDT introduces formation of inter-organizational relationships as a strategy for firms to deal with environmental uncertainly, it does not explain how they help firms acquire necessary resource to mitigate the uncertainty (Harrigan \& Newman, 1990; Hillman et al., 2009). Second, according to Gulati (1995: 620), looking at alliance formation solely from RDT perspective, "does not examine how firms learn about new alliance opportunities and overcome the fears associated with such partnerships". Finally, interdependency among

\footnotetext{
* Corresponding author.

E-mail addresses: j3zhang@odu.edu (J. Zhang), apezeshkan@ubalt.edu (A. Pezeshkan).

${ }^{1}$ These two authors contributed equally to this work.
}

firms has a dynamic nature (Casciaro \& Piskorski, 2005; Katila, Rosenberger, \& Eisenhardt, 2008); that is, the magnitude and nature of firms' dependency on others may change over time. Yet, RDT "focuses on the need for critical resources and the necessity for social exchange, rather than the more complex theoretical challenge of describing how competencies are developed and how inter-firm transfers of competencies actually take place" (Barringer \& Harrison, 2000: 374). With firms becoming more competent, the dynamic of interdependency between them changes and so does their alliance behavior. However, RDT provides a relatively static perspective and does not consider such dynamics.

Responding to these gaps, scholars suggest that integrating RDT with other perspectives especially social network theory, "which shares many common assumptions regarding dependence but emphasizes the socially embedded context of firms" (Hillman et al., 2009: 4), would create a more comprehensive understanding of inter-organizational linkages. Social network perspective helps explain alliance formation within a rich social context in which firms collect, disperse and exchange information with prospective partners and thus help firms learn about new alliance opportunities. It also portrays the changes in inter-organizational relationship due to changes in firms' network attributes and consequently their competencies.

Prior studies that have solely applied social network theory to examine international alliance formation also have limitations. One major limitation is that most of the prior studies have focused on information and resource flow in the network (e.g., Shi, Sun, Pinkham, \& Peng, 2014); therefore, although they can well explain 
how firms with certain network features convey information about themselves to prospective partners in the network and thus attract ideal partners (Benjamin \& Podolny, 1999; Shi et al., 2014), they largely ignore that network features also impact firms' own dependence on partners and thus willingness to ally (Ahuja, 2000). Due to mutual dependence (i.e., interdependence) between firms, both parties' willingness and attractiveness in alliance formation should be analyzed (Eisenhardt \& Schoonhoven, 1996).

To fully take advantage of RDT and social network theory, this study incorporates both theories to examine the question: how does foreign firms' existing position in the network they develop in the host country influence their decision to establish further alliances? We introduce network centrality as a factor that influences two competing forces in alliance formation - willingness and attractiveness (Ahuja, 2000; Eisenhardt \& Schoonhoven, 1996). We develop this dual rationale of alliance formation by highlighting the paradox faced by foreign firms; that is, as their centrality increases, firms become more attractive in the eyes of other peers; however, after a threshold, their willingness to ally may start declining (i.e., they become less dependent on partners). Moreover, we explain different forms of interdependence in the alliances of foreign firms with local firms versus with firms from their home country.

The cyclical relationship between network position and alliance formation suggests that foreign firms new to the host country will find it harder to move to the center of network. To introduce a solution, we propose that factors exogenous to the host country network may change interdependence among firms, and thus reduce the level of path dependence in alliance formation process. Specifically, we propose that industry experience will play such a moderating role.

Our theoretical propositions are tested on a novel data set composed of the population of US venture capital (VC) firms that invested in mainland China between 1997 and 2010. These US VC firms were selected mainly because they represent the firms from developed countries entering emerging economies, for which using alliances is the dominant strategy (Lu \& Hwang, 2010). In addition, China has been the largest importer of VC funds and the United States has been the largest exporter (Wang \& Wang, 2011).

This study makes three primary contributions. First, it is among the early efforts to fully integrate RDT and social network theory in depicting the dynamic of alliance formation. This is a direct response to the call by Hillman et al. (2009) for research enhancing the explanatory potential of RDT via its integration with other relevant theories. Our main hypotheses suggest an inverted Ushaped relationship between US VC firms' centrality and the number of Chinese/US partners in new alliances. We argue that while a central position of foreign firms may increase their attractiveness and thus partners' dependence on them, it also reduces their dependence on partners after reaching a certain level. Moreover, industry experience as an exogenous variable weakens the relationship between existing network centrality and further alliance formation through influencing the interdependence between firms. The dynamic relationship between network position, interdependence, and new alliance formation offers a unique setting to observe the emergent structuration of a network that influences firm behavior (Giddens, 1984).

Second, we explore an important but neglected research question in the international business literature: how do foreign firms ally with others from their home country? The literature suggests that cultural and institutional distances ${ }^{2}$ can function as

\footnotetext{
${ }^{2}$ Cultural and institutional distances refer to the extent of dissimilarity between regulatory, cognitive, and normative institutions as well as underlying differences in national cultures between home and host countries (Chao \& Kumar, 2010; Trevino \& Mixon, 2004).
}

a challenging barrier to a successful inter-firm collaboration (Ahlstrom, Young, Nair, \& Law, 2003; Ahlstrom, Levitas, Hitt, Dacin, \& Zhu, 2014; Nielsen, 2007; Sun, Peng, Lee, \& Tan, 2015), and familiarity with potential partners' capability and reliability plays a critical role in alliance formation (Li \& Rowley, 2002). Hence foreign firms may partner with others from their home country. However, such foreign-foreign dyad has not yet been explored much.

Third, recent years have witnessed a constantly increasing number of VC firms from developed countries investing in emerging economies (Chemmanur, Hull, \& Krishnan, 2012; Pruthi, Wright, \& Lockett, 2003). Most of the prior studies have focused on cross-country comparison of VC industry (e.g., Jeng \& Wells, 2000; Li \& Zahra, 2012; Manigart et al., 2000, 2002). Although these studies provide an excellent picture of VC industry across different countries and clarify its variation in different contexts, they do not explain specific challenges that VC firms face when managing cross-border investments (Mäkelä \& Maula, 2006). Additionally, strategic behavior of VC firms when investing across borders still remains under-studied (Jääskeläinen, 2012; Meuleman \& Wright, 2011). Hence, this study is timely and empirically important, as it helps uncover one of the most important and common strategic behaviors - syndication of VC firms (Barry, 1994; Lerner, 1994a) when they commit to international investments.

\section{Research context}

We study syndication in the VC industry to develop and test our theoretical framework for the following reasons. First, VC industry is regarded as an "intensely social business" (Guler \& Guillén, 2010: 391), and syndication is a common strategy in this industry (Barry, 1994; Lerner, 1994a). Syndication arises when two or more VC firms jointly invest in a venture (Brander, Amit, \& Antweiler, 2002). VC firms syndicate for a number of reasons. Besides spreading investment risks, syndication helps firms share resources and capabilities to benefit from complementary knowledge and expertise in pre- and post-investment activities (Hopp \& Rieder, 2011; Lerner, 1994a). In addition, since VC firms tend to specialize in certain industries, they need partners when there is a compelling investment opportunity beyond their domain of expertise (De Clercq \& Dimov, 2004). In fact, "syndication networks will only be broadened if potential new partners can offer additional value beyond the current composition of incumbent syndicate members" (Hopp, 2010: 430). In a syndicated deal, different parties are expected to perform different roles according to their specific capabilities (Wright \& Lockett, 2003). It creates the collaborative nature of syndication. Therefore, syndication is the equivalent of alliance in the VC industry where there is a strong need for cooperation and collaboration among parties to achieve shared objectives (Wright \& Lockett, 2003).

Second, previous studies have found that VC firms' position in their network, which is the focus of our study, is an important signal of trustworthiness and quality (Gompers \& Lerner, 2001; Hochberg, Ljungqvist, \& Lu, 2007; Nahata, 2008; Stuart, Hoang, \& Hybels, 1999); thus, it is very likely to affect firms' attractiveness and willingness to syndicate.

In this study we examine the population of US-domiciled VC firms that invested in China. The "Chinese VC industry is the largest private equity in the Asia" (Batjargal, 2007: 999). Along with the fast growth of China's economy in recent years, the country's VC industry has grown exponentially. In 2012, approximately $\$ 25.3$ billion VC funds were raised in China, up from \$325 million in 2002 (zero2ipo research, 2013). The Chinese VC industry creates substantial growth opportunities for VC firms from developed countries such as the United States (Wright, Pruthi, \& Lockett, 
2005), which has the oldest and largest VC industry in the world (Black \& Gilson, 1998; Gilson, 2003).

\section{Theoretical development and hypotheses}

\subsection{Resource dependence theory and international alliances}

As one of the primary theoretical perspectives examining interorganizational relationships, RDT considers interdependence among firms the major motivation to form alliances (Hillman et al., 2009). According to Pfeffer and Salancik (1978: 52) interdependence is a phenomenon that "exists whenever one actor does not entirely control all of the conditions necessary for the achievement of an action or for obtaining the outcome desired from the action". Organizations form alliances when "they perceive critical strategic interdependence with other organizations in their environment" (Gulati, 1995: 621). Thus, strategic alliance is used as a governance mechanism to reduce uncertainty and manage dependence (Drees \& Heugens, 2013). Firms use alliances to acquire critical resources that they lack to achieve their desired outcomes (Bae \& Insead, 2004). Such resources can be tangible such as capital (Dacin, Hitt, \& Levitas, 1997; Hitt, Dacin, Levitas, Arregle, \& Borza, 2000), and intangible such as legitimacy (Baum \& Oliver, 1991), technological know-how and capabilities (Contractor \& Woodley, 2015; Lei, Slocum, Pitts, 1997; Mowery, Oxley, \& Silverman, 1996), and access to a new market (Baum, Calabrese, \& Silverman, 2000). The value of resource and capability acquisition through alliances is particularly prominent when environmental uncertainty is high (Heide, 1994; Young-Ybarra \& Wiersema, 1999), which is the case when firms enter a foreign country.

Previous studies in international business have focused on foreign-local dyadic alliances (e.g., Hitt et al., 2000; Meuleman \& Wright, 2011; Shi et al., 2014). In the particular context of foreign firms from a developed country entering an emerging economy (i.e., the context of this study), RDT suggests a clear interdependency between the foreign and local firms. On the one hand, local firms are eager to learn the best practices and access resources that are either scarce or unavailable in their home country (Dong \& Glaister, 2006; Levin \& Barnard, 2013). On the other hand, foreign firms depend on local counterparts to overcome liability of foreignness (LOF) (Bell, Filatotchev, \& Rasheed, 2012; Zaheer, 1995), because local partners are capable of providing them with access to local and regional markets and customers, governmental and other institutional actors, and regulatory permits (Gillespie \& Teegen, 1995; Hitt et al., 2000; Kotabe et al., 2000).

While RDT offers important insights into alliance formation, it does not examine how firms learn about alliance opportunities and choose the right partners, because it assumes that firms operate in an atomistic environment where information is freely available and equally accessible to every firm (Gulati, 1995). However, the assumption does not stand in the real life. Different firms in a network have different levels of access to information available in the network, depending on their position in and structure of the network (Guler \& Guillén, 2010). Responding to this important research gap, scholars have called for studies to incorporate social network theory with RDT to examine the social context where firms learn about prospective alliance partners and send out information when they intend to ally (Hillman et al., 2009).

\subsection{Social network theory, centrality, and international alliances}

Although prior studies have adopted social network theory in examining alliance formation, they have not fully integrated the concept of interdependence from RDT in analysis. Some studies have examined the impacts of dyad-level constructs such as tie strength (Wong \& Ellis, 2002) and repeated ties (Gulati, 1995), and some investigated network-level constructs such as multiplexity (Beckman, Haunschild, \& Phillips, 2004), clustering patterns among partners (Nair, Hanvanich, \& Cavusgil, 2007), and local partners' network position (Shi et al., 2014). These studies have focused only on the information and resources flowing in the network, and thus they have viewed focal firm's network attributes as factors making the firm attractive for prospective partners (Benjamin \& Podolny, 1999); however, they largely ignored the firm's willingness to ally. Since interdependence is reciprocal in nature, attractiveness and willingness of both parties should be analyzed.

In this study, we introduce foreign firms' network centrality as an important network construct that links social network theory with RDT. In social network analysis, centrality refers to the extent to which the focal firm has "a large number of connections with the other points in its immediate environment" (Scott, 1991: 84). A firm's network centrality has a profound impact on its alliance behavior (Benjamin \& Podolny, 1999; Higgins \& Gulati, 2003; Ozmel, Reuer, \& Gulati, 2012; Podolny, 2001). In this study we focus on network centrality, because it complements RDT as a foundational perspective in understanding inter-firm relationship formation. First, according to RDT firms look for complementary resources when forming alliances (Park, Chen, \& Gallagher, 2002), and one of the major functions of a network is providing a context for firms to send and receive signals about each other's competencies in their search for partners (Podolny, 2005). In emerging economies such as China, local network represents a major channel for critical resources and information to flow among market players (Keister, 2009; Lu \& Hwang, 2010). Among all network traits, centrality is perhaps the most prominent and reliable signal that both foreign and local firms may refer to in evaluating prospective partners' ability and social status (Damanpour, Devece, Chen, \& Pothukuchi, 2012; Sorenson \& Stuart, 2001). Further, compared with other important network traits such as brokerage, centrality is the most easily available and ready-toevaluate indicator (Shi et al., 2014). For all firms, and in particular foreign firms, it is hard to collect complete information about the entire local business network in order to identify the brokers, but it is relatively more feasible and less expensive to learn about the most centrally located firms (Shi et al., 2014). Since we focus on foreign firms in this study, network centrality is a more applicable construct than brokerage for foreign firms to utilize as a strategic tool to signal their competency.

Second, according to RDT, lack of strategic resources is the underlying factor creating interdependence between firms and leading them to ally (Pfeffer \& Salancik, 1978). Determining the firm's likelihood of accessing different resources available in the network (Guler \& Guillén, 2010; Hochberg et al., 2007; Podolny, 2001), the focal firm's network centrality influences the magnitude of uncertainty that its managers perceive from the environment and consequently their dependence on others. Thus, network centrality also indicates the extent to which the focal firm is willing to enter into alliances.

\subsection{US VC firms' syndication with Chinese VC firms}

In recent years, an increasing number of VC firms from the United States and other developed countries have expanded into emerging economies such as China to explore new investment opportunities (Dai, Jo, \& Kassicieh, 2012). This trend also offers tremendous opportunities for Chinese firms. First, compared to the United States where the VC industry originated, China has a nascent VC industry (Ahlstrom \& Bruton, 2006; Wright et al., 2005). Chinese VC firms can learn best practices in the industry from US partners, including pre-investment activities (e.g., screening and 
assessing values) and post-investment activities (e.g., assisting ventures in recruiting experienced executives, planning and expansion, and acquiring resources) (Kaplan \& Strömberg, 2001; Steier \& Greenwood, 1995). Second, syndicating with US VC firms extends the investment horizon for Chinese VC firms and enables them to enter the United States and other foreign markets which their US partners have already explored, because entering a foreign market is much easier if the firm has established relationships with insiders (Hochberg et al., 2007). Third, in recent years increasingly more Chinese companies have pursued initial public offerings (IPOs) in the US stock market, which has less restriction on company's profitability and offers larger capital pool and better legal protection to the issuer companies than the Chinese stock market (Ahlstrom \& Bruton, 2006; Wright \& Robbie, 1998). Many leading Chinese IT/Internet companies, including Alibaba, Baidu, NetEase, Sohu, and Sina are listed in the United States. All of these companies received US VC investment before IPOs. Studies have suggested that involvement of US VC firms can substantially facilitate foreign IPOs in the United States (Hursti \& Maula, 2007). Finally, US VC firms can help the VC investment team exit the venture through arranging mergers and acquisitions. Because the United States has more incumbent and established companies than China (Hitt et al., 2000), US VC firms have the advantage to find more potential acquirers. Such resources and capabilities that US firms possess and are not extensively available among Chinese firms create Chinese VC firms' dependence on them, and make US VC firms attractive partners.

US VC firms are also dependent on local firms when entering China, because they suffer from substantial LOF, which "mainly refers to additional costs in VC investments due to the knowledge and network disadvantage VC firms experience in overseas market" (Lu \& Hwang, 2010: 83). US VC firms not only have great difficulties in operating within the Chinese culture and institutional system, but also lack connections to local businesses and government agencies, as well as local deal information (Bruton, Ahlstrom, \& Yeh, 2004). Through syndication, Chinese VC firms provide US partners with market knowledge and help them find promising investment deals. In addition, Chinese VC firms' familiarity with the institutional environment and legal requirements helps US VC firms operate more effectively in China (Dai et al., 2012; Wright et al., 2005). Therefore, US VC firms are initially willing to syndicate with Chinese counterparts. Because of the interdependence between Chinese and US VC firms, it is common to see Chinese-US syndicates when US VC firms enter China.

After US VC firms start operating in China, their existing position in the Chinese syndicate network will influence their further alliance behavior. We predict that a more central position will amplify their attractiveness for Chinese VC firms and thus introduce more syndicate opportunities for US VC firms due to two major reasons. First, reaching a central position in China, which has a remarkably different business environment from that of US, shows the international operation capability of the US VC firms (Baum et al., 2000). It signals their ability to build and sustain syndicate networks and connect potential Chinese partners and their portfolio ventures to the United States and other foreign markets (Swaminathan \& Moorman, 2009). Second, a central position implies a large number of extant alliance partners, through which the US firm can obtain resources and information (Hoang \& Antoncic, 2003; Sparrowe et al., 2001) and thus have a higher likelihood of investment success.

After US VC firms reach a certain level of network centrality in the host country, however, their dependence on Chinese partners starts decreasing, and therefore they may not be willing to ally with as many Chinese partners as they were before. During their operation to gain such position, they have adapted to ways of doing business in China, mastered market knowledge, and developed access to institutional actors (Guler \& Guillén, 2010; Hochberg, Ljungqvist, \& Lu, 2010; Meuleman \& Wright, 2011). Therefore, benefits of learning from local partners to overcome LOF are minimized. In addition, as "voluntarily initiated cooperative agreement between firms" (Gulati and Singh, 1998: 781), alliances are susceptible to opportunistic behaviors due to VC firm time and resource constraints (Gifford, 1997) and the "uncertainty about the partner and its changing goals" (Steensma, Marino, Weaver, \& Dickson, 2000: 953). Weak regulatory protection in China further increases the likelihood of opportunistic behavior such as freeriding $^{3}$ and consequently increases investment risks (Dimov \& De Clercq, 2006; Manolova, Manev, \& Gyoshev, 2010; Meuleman, Wright, Manigart, \& Lockett, 2009). Such risks in addition to the reduced value added by local firms decrease US VC firms' willingness to syndicate with Chinese VC firms. ${ }^{4}$

Despite their capability to attract a large number of partners (Keil, Maula, \& Wilson, 2010), centrally positioned US VC firms may prefer solo investment or syndication with fewer but high-status partners for the following reasons. First, high-status partners not only bring more valuable tangible and intangible resources to the deal and thus enhance the investment performance (Hochberg et al., 2007), but also will be less likely to conduct opportunistic behavior (Gulati, Nohria, \& Zaheer, 2000), since they know such behavior will damage their reputation and result in non-legal sanctions by both fellow VC firms and entrepreneurs in future deals (Hochberg et al., 2010). Second, following the above logic, after reaching a central position, the focal US VC firms are highly concerned with maintaining their own reputation (Wright \& Lockett, 2003). As a result, they become more selective (Hochberg et al., 2010; Lerner, 1994a). For them, investing with lower-status partners can result in a "status leak", since they have much more to lose if the investment fails (Guler \& McGahan, 2007; Podolny, 2005). Further, they may face punishment from other high-status fellows after syndicating with low-status VC firms. That may reduce the likelihood of them being invited into syndicates with other high-status firms (Hochberg et al., 2010). Third, having fewer partners reduces the likelihood of free-riding and other forms of opportunistic behavior (Hochberg et al., 2010). Prior studies have found a negative relationship between the number of partners and the magnitude and effectiveness of value-adding activities (Casamatta \& Haritchabalet, 2007; Kaplan \& Strömberg, 2004). In addition, having fewer partners reduces the excessive time and effort that the focal US VC firms have to spend to coordinate their relationships. It merits noting that with high-status the US VC firms also tend to avoid acting opportunistically and misusing their position in order to protect their reputation (Gilson, 2003); therefore it is less likely that they will enter into a large size syndicate to free-ride. In sum, after US VC firms reach a certain level of centrality, we expect to see fewer Chinese partners in their syndicates. Thus, we predict:

\footnotetext{
${ }^{3}$ Free riding in syndication is an opportunistic behavior where one party avoids cooperating while expecting to acquire benefits from other parties' effort (Dimov \& De Clercq, 2006). Other instances of opportunistic behaviors include withholding or distorting information, collusion with entrepreneurs, and overstating the price for the next round of financing (Gompers \& Lerner, 1996; Lerner, 1994a; Wright \& Lockett, 2003).

${ }^{4}$ It is noteworthy that there are two competing forces influencing US firms' willingness to syndicate with Chinese firms. On the one hand, above mentioned risks negatively impact US VC firms willingness. On the other hand, the LOF that they experience necessitates partnering with Chinese firms. We argue that before US firms possess a central position, their needs stemming from LOF dominate the equation; therefore, they still lean toward syndication. When inter-partner trust is low, they may rely on contractual mechanisms against opportunistic behaviors (Das \& Teng, 2001). Recent studies have confirmed the importance of contracts in managing alliances in China (e.g., Chen \& Chen, 2003; Wang \& Nicholas, 2007). However, after reaching a central position, the LOF reduces and so does VC firms' willingness to ally. Thus the negative impact of risks involved in syndication may dominate the equation and make US VC firms selective in using Chinese partners.
} 
Hypothesis 1. There is an inverted U-shaped relationship between a US VC firm's extant network centrality in China and the number of Chinese partners in its syndicates.

\subsection{US VC firms' syndication with other US VC firms}

While syndicating with Chinese partners may help US VC firms, mainly through overcoming LOF, syndicating with other US VC firms may also facilitate the focal US VC firms' investment in China, but for different reasons. Besides general benefits of syndication, such as pooling capital and skills, learning investment knowledge, and sharing financial losses (Lerner, 1994a), US VC firms also face less LOF if they syndicate with other US partners who have come to China earlier and mastered certain local knowledge. Moreover, familiarity with potential partners' capability and reliability plays a critical role in US-US syndication (Li \& Rowley, 2002). Coming from the same home country, US VC firms, to a great extent, share investment philosophy and practices in the investment cycle, from assessing risks, selecting and monitoring ventures to preferred exit methods (Bruton \& Ahlstrom, 2003; Pruthi et al., 2003; Wright, Lockett, \& Pruthi, 2002; Wright et al., 2005). The familiarity between partners not only mitigates managerial risks in the investment process (Brander et al., 2002; Guler \& Guillén, 2010; Sorenson \& Stuart, 2008), but also results in trust in both parties and thus enhances the likelihood of collaboration (Johnson, Cullen, Sakano, \& Takenouchi, 1996; Madhok, 2006). Vulnerability and risks involved in foreign investments increase perceived uncertainty by US VC firms and create interdependence between them (Murray, Kotabe, \& Zhou, 2005). Thus, they are generally willing to syndicate with other US counterparts to overcome such uncertainty.

After the focal US VC firms continue their operation in China, their existing network position will influence their further syndications. The firms occupying a higher central position are more attractive for other US VC firms for two reasons. First, higher network centrality indicates a higher level of social status (Guler \& Guillén, 2010) and thereby a higher level of legitimacy and trustworthiness (Dacin, Oliver, \& Roy, 2007; Eisenhardt \& Schoonhoven, 1996; Glaeser, Laibson, Scheinkman, \& Soutter, 2000; Stuart, 2000). That reveals the capabilities of focal firms in identifying and managing investment deals. Second, a high centrality signals focal firms' connections and thus familiarity with the local market. Although focal US VC firms may not be as familiar with the host market as Chinese firms are, they still can be a reliable source of economic, political, social, and cultural knowledge of the Chinese market (Lu \& Beamish, 2006), and thus help their home country partners deal with problems stemming from LOF.

Despite their enhanced attractiveness, after reaching a certain level of centrality, focal US VC firms' willingness to syndicate may decrease. Along with development of their network in China, focal VC firms obtain more knowledge about the local market and institutional environment, which increases their competency in handling investment deals and decreases their perceived uncertainty. With reduced perceived uncertainty which is the major factor making US VC firms dependent on each other, centrally positioned firms may not be willing to share investment profits with many partners (Brander et al., 2002). Additionally, conflicts between partners exist even though they are from the same home country (Sahlman, 1990). Following the similar logic for Hypothesis 1, we argue that they are likely to undertake standalone investment, or syndicate with fewer but high-status US partners. In summary, we predict:

Hypothesis 2. There is an inverted U-shaped relationship between a US VC firm's extant network centrality in China and the number of US partners in its syndicates.

\subsection{Compensation effects of US VC firms' industry experience for low centrality}

In the preceding section, we argued that US VC firms' current network position determines their further syndication behavior. In particular, for those with relatively low level of centrality (before the inflection point as stated in Hypotheses 1 and 2), the lower their network centrality, the more difficult to form syndicates. The nature of path-dependency in alliance formation challenges US firms in their operation in China; that is, it will be difficult for peripheral firms (i.e., those with low centrality) to move to the center of the network (Gulati, 1995). As a result, such firms continue suffering from the liability of outsidership (LOO). As Johanson and Vahlne (2009: 1415) stated, "a firm that does not have a position in a relevant network is an 'outsider.' If a firm attempts to enter a foreign market where it has no relevant network position, it will suffer from the liability of outsidership and foreignness, and foreignness presumably complicates the process of becoming an insider".

This section is aimed to suggest remedies for peripheral US VC firms to overcome LOO and consequently LOF in China. Applying RDT and attractiveness-willingness framework, we argue that US VC firms' industry experiences is an important factor that may change the interdependence between them and prospective partners, and thus may moderate the impact of existing network position on further syndicate formation.

Prior research has found that firms' general experience in the VC industry is a significant factor leading to investment success (Abell \& Nisar, 2007). Industry experiences include expertise in finding and selecting promising investment opportunities in the preinvestment stage and capabilities in leading ventures toward a successful exit by offering value-adding services in the postinvestment stage (Gompers, Kovner, Lerner, \& Scharfstein, 2010). For instance, compared to less experienced ones, experienced VC firms can more skillfully tailor investment contracts to minimize transaction costs (Meuleman et al., 2009), better monitor and advise ventures in operation (Kaplan \& Strömberg, 2001; Martí, Menéndez-Requejo, \& Rottke, 2013), and help ventures draft more effective strategies and acquire necessary resources (Gompers et al., 2010). Also, experienced VC firms are more competent in exiting new ventures through IPO (Lerner, 1994b).

When experienced US VC firms first come into China, they lack local connections and linkages and thus inevitably suffer from both LOO and LOF. We argue that compared to less experienced counterparts, these VC firms will find it easier to overcome the path-dependency constraint stemming from their existing network position. Particularly, industry experience will compensate for their lack of attractiveness which is due to their low centrality.

The reason is twofold. First and the fundamental reason is that the US VC firms' experience indicates that they have been active in the VC industry for a long time and have accumulated rich knowledge about both pre- and post-investment activities. Learning such knowledge is a remarkable opportunity for Chinese VC firms. The more experienced the US VC firms are, the more notable the learning opportunity for Chinese partners is (Abell \& Nisar, 2007; Lu \& Hwang, 2010). Second, having more experience also implies that the US VC firms have broader access to resources and connections in the United States and other countries (Gompers et al., 2010), which can be leveraged in their Chinese investments and future collaboration in the international market. US VC firms' knowledge and resources increase Chinese partners' dependence on them and, to some extent, compensate for the lack of attractiveness due to their low centrality. Therefore, US VC firms with richer industry experience will suffer less from their existing low network centrality, and thus the effect of centrality on syndication will be weaker. 
By the same token, knowledge and resources of focal US VC firms will play the same role when they syndicate with other US VC firms. In fact, since they come from the same home country, prospective US partners would have even more knowledge about the experience and thus capabilities of the focal US VC firms. Therefore, for US VC firms with rich industry experience, their existing low network centrality in China would not strongly impact prospective US partners' judgment on their capabilities.

To illustrate the argument, suppose when a well-established US VC firm, e.g., Sequoia Capital, first enters China, many Chinese/US VC firms would try to pursue a joint investment opportunity, despite Sequoia Capital's low centrality in China. This is because the prospective partners foresee subsequent advantages of affiliation with such an experienced firm (Guler \& Guillén, 2010). In contrast, for a US VC startup that does not carry such a prestigious status and extensive experiences, its existing network centrality would be used more considerably by prospective partners to evaluate its capabilities.

In summary, the focal US VC firms' industry experience will compensate for the lack of attractiveness due to low centrality. Compared to less experienced ones, "more experienced venture capitalists generate better signals" (Casamatta \& Haritchabalet, 2007: 370). Such strong signal reduces the importance of their network centrality as a signal of their capabilities. Hence, the impact of network centrality on syndication would be weaker when the industry experience is higher.

Recall that the impact of centrality on the number of Chinese/ US partners is proposed to take an inverted-U shape in Hypotheses 1 and 2 ( $\mathrm{H} 1$ and $\mathrm{H} 2$ ). We now focus on the left-hand side of the curve before the inflection point, where the focal US VC firms have relatively low level of centrality. According to the logic outlined above, we propose that with increasing levels of industry experience, the slope of the left hand side of the centrality curve, which is positive, will become flatter, since industry experience will to some extent compensate for the positive effect of centrality and reduce its impact on further syndication. In other words, industry experience reduces the strength of the relationship between network centrality and number of partners. Accordingly,

Hypotheses 3a and 3b. For US VC firms with relatively low levels of centrality in the Chinese syndicate network (before the inflection point of the curves described in $\mathrm{H} 1$ and $\mathrm{H} 2$ ), their industry experience will flatten the slope of the positive effect of their network centrality on the number of Chinese partners (H3a) or US partners (H3b) in their syndicates.

\section{Methodology}

\subsection{Data and sources}

We test the hypotheses with data on US-domiciled VC firms and their investments in China between 1997 and 2010. The Chinese VC industry experienced exponential development during this period in terms of capital available for investment and the number and amount of actual investment (Ahlstrom, Bruton, \& Yeh, 2007).

We compiled the VC investment data from two databases: VentureXpert and Zero2IPO. VentureXpert has been used extensively in VC research (Barry, Muscarella, Peavy, \& Vetsuypens, 1990; Gompers \& Lerner, 2000; Guler \& Guillén, 2010; Megginson \& Weiss, 1991; Sahlman, 1990; Shane \& Stuart, 2001). To eliminate potential problems caused by lower coverage of VentureXpert in the early period in China, we also collected data from Zero2IPO (http://www.pedaily.cn/en/). The Chinese database has the most comprehensive coverage on Chinese deals, though the information on US VC firms is more limited compared with VentureXpert. More than $98 \%$ of the deals covered in the two databases overlap after
1997. Therefore, we integrated the two databases and collected investment deal data after 1997. Although studies have suggested that China was not seriously hit by the world or regional economic/ financial crises during this period, such as the Asian Financial Crisis (1997-1999) (Fernald \& Babson, 1999; Yellen, 2007), these events may still have influences on the external financial environment, and thus VC investment activities in China. Addressing this concern, we ran year-fixed models to control for any year effects in hypothesis tests. We also excluded the 76 cases during years 1997 and 1999 from the dataset as a robustness test, and the results largely remained.

The data include complete population of US firms that invested at least once in Chinese ventures in 1997-2010. As of the end of 2010, 250 US VC firms had made 870 rounds of investment in 783 ventures in mainland China. The largest investors were Warburg Pincus, Sequoia Capital, and Intel Capital. The distribution of rounds by investment stage is startup or seed (3\%), early stage (9\%), venture capital (65\%), and expansion (23\%).

\subsection{Measures}

\subsubsection{Dependent variable and unit of analysis}

The unit of analysis is the investment round - VC firm. Each round has at least one US firm, which is the focal firm. In the case of multiple US investors, we have multiple observations. For instance, if GSR Ventures (China), International Finance Corporation (US), and Mayfield Fund (US) co-invested in one deal, there will be two observations, where the focal firm is International Finance Corporation and Mayfield Fund, respectively.

The dependent variable is the number of Chinese/US partners in the deal from the focal US VC's perspective. For solo investment deals where no co-investors are involved, the dependent variable is " 0. "

\subsubsection{Independent variable}

Following previous research, we measured network centrality using Bonacich's (1987) eigenvector centrality measure (Guler \& Guillén, 2010). There are three most commonly used measures of centrality in social science: degree centrality, betweenness and closeness (Peng, Au, \& Wang, 2001). Degree centrality counts the number of links an actor has. Betweenness counts the number of times an actor acts as a bridge along the shortest path between two other actors, so it quantifies the control of an actor on the communication between other actors in the network. Closeness is regarded as a measure of how long it will take to spread information from an actor to all other actors sequentially. It does not only consider the number of links an actor has, like "degree centrality", it also takes into account their quality. A particularly useful measure of closeness is "eigenvector centrality" (Bonacich, 1987), which essentially is a recursive measure of degree, whereby the actor's centrality is the sum of her ties to other actors weighted by their centralities (Hochberg et al., 2007). Therefore, firms connected to centrally positioned partners will also have a high centrality. In the alliance formation context, since information and resources flow within the whole network, partners' partners are also important agents that influence the focal firms' quality perceived by partners (Sorenson \& Stuart, 2001). Hence, eigenvector is a better measure of centrality than alternative measures in this context (Jensen, 2003; Nerkar \& Paruchuri, 2005; Podolny, 1993, 1994).

We considered a tie to exist only if two firms invested together in the same Chinese venture and in the same round. We incorporated all VC firms in the networks, including US and Chinese firms and firms from other countries. For each year $t$, we calculated the centrality score using investment deals in the last three years $(t-2, t-1$, and $t$ ) (Castilla, 2005; Guler \& Guillén, 
2010; Hochberg et al., 2007; Piskorski \& Anand, 2005). The centrality score for firm $i$ in year $t$ was modeled as follows:

$c_{i}=\alpha \sum A_{i j} c_{j}$

where $\alpha$ is the reciprocal of an eigenvalue and $A$ is the adjacency matrix denoting the existing ties between firms $i$ and $j$ in the threeyear window. The centrality of each firm $i$ is a function of the centrality of the other firms to which it is connected. We assigned a " 0 " to isolated firms with no ties to others. The centrality score ranges between 0 and 1 .

Following previous studies (Abell \& Nisar, 2007; Hochberg et al., 2007; Lee \& Wahal, 2004; Nahata, 2008; Wang \& Wang, 2011), the moderator industry experience is measured by the natural logarithm of the age of the VC firm when it made the particular investment. There is a one-year lag between the dependent variable and independent variables/moderator. In particular, we traced back to investment deals before 1997 to calculate early-year variables (e.g., we used deals in years 1994-1996 when calculating centrality 1996$)$.

\subsubsection{Control variables}

We controlled for the quality and thus risks of ventures by including various venture features. First, we included the number of US/Chinese partners when testing partnership with Chinese/US firms respectively. Since a diverse partnership in the deal would enhance the likelihood of success, having more US partners might attract more Chinese partners and vice versa.

Second, we controlled the round of investment and the natural logarithm of the age of ventures upon receiving the round of investment. Because early rounds and young ventures imply more financial risks, US VC firms may invest in late rounds and established ventures. In the same vein, we controlled the stage of investment by including a set of dummies - startup stage, early stage, and VC stage, while keeping the expansion stage as the reference group.

We also included the industry dummies IT and medical, while keeping other industries as the reference group. On one hand, information technology (IT) and healthcare/medical industries bear high financial risks and high return, which will influence VC investors' choice; on the other hand, US VC firms could be experienced in investing in these industries, as the United States has seen successful growth in these industries with support from VC investment (Florida \& Kenney, 1988).
To control for geographic influence, we included three dummies for major cities, Beijing, Shanghai and Shenzhen, while keeping other cities as the reference group. Beijing is the capital of China; Shanghai and Shenzhen are the host cities of the Chinese stock exchanges. Most VC firms and other financial institutions are located in these cities. Ventures located there are better connected to the financial sector and thus easier to access and monitor. These factors help US VC firms evaluate and monitor ventures, and thus they may prefer to invest in these cities. Finally, we included a set of year dummies, while keeping the year 2010 as the reference group.

\subsection{Data analysis}

There are two critical methodological considerations in our data analysis. First, since our data contain multiple observations per firm, unobserved heterogeneity is a concern. Therefore, we incorporate fixed firm effects into all our models. Second, endogeneity is a potential concern. In most cases, it occurs when a model excludes variables that significantly influence both dependent and independent variables. Our approach minimizes potential endogeneity problems because lagging all independent variables helps ensure that the model does not use independent variables that were determined simultaneously with the dependent variable; in addition, including firm fixed effects helps control for time-invariant omitted variables (O'Brien \& David, 2014). Moreover, while techniques such as two-stage instrumental variables regression can be applied to eliminate the bias, the techniques are less efficient because they tend to produce much larger standard errors (Wooldridge, 2003, chapter 15). This means that "even if a variable is theoretically endogenous, it is preferable to not model it as endogenous unless tests indicate that it induces a statistical problem" (O'Brien \& David, 2014: 559). We created instruments for centrality (i.e., accumulated number of existing US/Chinese partners) and conducted the Davidson-MacKinnon test of exogeneity. The result suggests that endogeneity was not a problem in the models.

\section{Results}

Table 1 provides the descriptive statistics and correlation matrix. The absence of high correlations between the independent variables suggests that multicollinearity was not an issue. We confirmed this by calculating the variance inflation factors, which are all less than 10 (Neter, Wasserman, \& Kutner, 1990).

Table 1

Descriptive analysis and correlation matrix.

\begin{tabular}{|c|c|c|c|c|c|c|c|c|c|c|c|c|c|c|c|c|}
\hline & & 1 & 2 & 3 & 4 & 5 & 6 & 7 & 8 & 9 & 10 & 11 & 12 & 13 & 14 & 15 \\
\hline 1 & No of US partners & 1 & & & & & & & & & & & & & & \\
\hline 2 & No of Chinese partners & $.087^{* *}$ & 1 & & & & & & & & & & & & & \\
\hline 3 & Centrality & $.080^{* *}$ & .032 & 1 & & & & & & & & & & & & \\
\hline 4 & Industry experience & -.015 & .050 & $.154^{* *}$ & 1 & & & & & & & & & & & \\
\hline 5 & Host country experience & $-.199^{* * *}$ & -.003 & $.322^{* *}$ & $.372^{* *}$ & 1 & & & & & & & & & & \\
\hline 6 & Round & $.366^{* * *}$ & $.150^{* *}$ & $.068^{* *}$ & $.063^{*}$ & .028 & 1 & & & & & & & & & \\
\hline 7 & ln(Venture age) & $-.125^{* * *}$ & -.006 & $-.087^{* * *}$ & $.150^{* *}$ & $.194^{* *}$ & $.118^{* *}$ & 1 & & & & & & & & \\
\hline 8 & Information tech & $.250^{* *}$ & $.125^{* *}$ & $.087^{* *}$ & $-.146^{* *}$ & $-.126^{* *}$ & $.132^{* *}$ & $-.353^{* *}$ & 1 & & & & & & & \\
\hline 9 & Medical & $-.055^{*}$ & .007 & .010 & $.052^{*}$ & $.069^{* *}$ & $-.051^{*}$ & $.168^{* *}$ & $-.306^{* *}$ & 1 & & & & & & \\
\hline 10 & Beijing & $-.064^{*}$ & .008 & .005 & -.048 & -.036 & $-.096^{* * *}$ & -.050 & $.201^{* *}$ & -.049 & 1 & & & & & \\
\hline 11 & Shanghai & $.229^{* *}$ & $.052^{*}$ & .046 & $-.059^{*}$ & $-.074^{* *}$ & $.275^{* *}$ & $-.153^{* *}$ & $.067^{*}$ & -.041 & $-.544^{* *}$ & 1 & & & & \\
\hline 12 & Shenzhen & .021 & -.008 & -.014 & .011 & -.039 & .002 & $.120^{* *}$ & $-.072^{* *}$ & $.076^{* *}$ & $-.182^{* *}$ & $-.137^{* *}$ & 1 & & & \\
\hline 13 & Early stage & $-.125^{* * *}$ & -.029 & -.025 & .013 & $.139^{* *}$ & $-.076^{* *}$ & $-.071^{*}$ & .026 & .014 & .027 & $-.057^{*}$ & $-.056^{*}$ & 1 & & \\
\hline 14 & Startup & -.022 & -.008 & $-.053^{*}$ & -.048 & .031 & -.029 & $-.160^{* * *}$ & -.037 & .022 & $.057^{*}$ & .003 & -.039 & $-.057^{*}$ & 1 & \\
\hline 15 & VC stage & $.236^{* *}$ & $.052^{*}$ & $.132^{* *}$ & $-.107^{* * *}$ & $-.242^{* *}$ & $.273^{* *}$ & $-.160^{* * *}$ & $.351^{* *}$ & $-.135^{* *}$ & .044 & $.131^{* * *}$ & $.070^{* *}$ & $-.424^{* *}$ & $-.244^{* *}$ & 1 \\
\hline & Mean & 0.83 & 0.28 & 0.15 & 2.72 & 2.15 & 1.97 & 1.18 & 0.61 & 0.06 & 0.42 & 0.29 & 0.04 & 0.09 & 0.03 & 0.64 \\
\hline & S.D. & 1.58 & 0.55 & 0.19 & 1.02 & 1.40 & 1.42 & 0.96 & 0.49 & 0.23 & 0.49 & 0.45 & 0.20 & 0.29 & 0.18 & 0.48 \\
\hline
\end{tabular}

. Correlation is significant at the 0.05 level (2-tailed)

.** Correlation is significant at the 0.01 level (2-tailed). 


\subsection{Hypotheses test results}

We used STATA 12 software package to conduct Negative binomial regressions to test the hypotheses, because our dependent variable is the count of partners, which takes only discrete non-negative integer values. Compared with Poisson regressions, Negative binomial regressions can be used for overdispersed count data that is when the dependent variable variance exceeds the mean. In fact, Poisson model is nested within a Negative binomial model. When the estimate of the dispersion parameter, alpha, is zero, the Negative binomial model reduces to the Poisson model. If alpha is significantly greater than zero, the data are over-dispersed and are better estimated using a Negative binomial model than a Poisson model. In such case, the confidence intervals for the Negative binomial regression are likely to be narrower as compared to those from a Poisson regression model (Cameron \& Trivedi, 1998; Long, 1997).

We provided the results in Table 2. In models 1-4 (DV = number of Chinese partners) the Likelihood ratio (LR) tests suggested that the dispersion parameter alpha equaled zero; therefore, the models reduced to the simpler Poisson models. In models 5-8 (DV = number of US partners) the LR tests suggested that alpha is significantly greater than zero; therefore, the Negative binomial models reported here are more meaningful than Poisson models.

Hypotheses 1 and 2 ( $\mathrm{H} 1$ and $\mathrm{H} 2$ ) predict an inverted-U shaped curve between centrality and number of Chinese (US) partners. In model 2, the coefficients for "centrality" and "(centrality) $)^{2}$ " are $3.056(p<0.01)$ and $-4.933(p<0.01)$. Moreover, the LR test shows that compared to Model 1 the LR Chi ${ }^{2}$ value in Model 2 is significantly increased $(p<0.01)$. Similarly, in model 6 , the relevant coefficients are $1.903(p<0.05)$ and $-2.509(p<0.05)$, and compared to Model 5 the LR Chi ${ }^{2}$ value in Model 6 is significantly increased $(p<0.05)$. The results suggest that the number of Chinese (US) partners at first increases and then decreases as centrality increases, and the changes have significant impacts. So, $\mathrm{H} 1$ and $\mathrm{H} 2$ are supported.

Hypotheses $3 a$ and $3 b$ ( $\mathrm{H} 3 \mathrm{a}$ and $\mathrm{H} 3 \mathrm{~b}$ ) predict that when centrality is low (before the inflection point) with an increasing level of industry experience, the positive impact of centrality on the number of Chinese (US) partners will become weaker. Results in model 4 of Table 2 do not support H3a (regarding Chinese partners) because the coefficients for the interaction terms "centrality * industry experience" and "(centrality) ${ }^{2} *$ industry experience" are insignificant. The LR test shows that compared to Model 3 the LR Chi ${ }^{2}$ value in Model 4 is not significantly increased $(p>0.10)$. With regard to H3b (US partners), model 8 shows that the coefficient for "(centrality) $)^{2}$ industry experience" is 1.743 $(p<0.05)$ and for "centrality * industry experience" is -1.061 $(p<0.10)$. Also, the LR test shows that compared to Model 7 the LR Chi $^{2}$ value in Model 8 is significantly increased $(p<0.05)$.

To visually present the effect of the non-linear interactions, we plotted the results of $\mathrm{H3a}$ and $\mathrm{H} 3 \mathrm{~b}$ tests in Figs. 1 and 2. Following the conventional approach (Aiken \& West, 1991), the low and high levels of industry experience are identified based on one standard

Table 2

Regressions predicting the number of chinese (US) partners ( $n=1213)$ (H1, H2 and H3).

\begin{tabular}{|c|c|c|c|c|c|c|c|c|}
\hline & \multicolumn{4}{|c|}{ DV: Number of Chinese partners (Poisson regressions) } & \multicolumn{4}{|c|}{ DV: Number of US partners (negative binomial regressions) } \\
\hline & Model 1 & Model 2 & Model 3 & Model 4 & Model 5 & Model 6 & Model 7 & Model 8 \\
\hline \multicolumn{9}{|l|}{ Predictors } \\
\hline Centrality & & $3.056^{* *}(1.062)$ & $3.016^{* *}(1.068)$ & $2.958^{* *}(1.062)$ & & $1.903^{*}(.768)$ & $1.888^{*}(.768)$ & $5.021^{*}(2.331)$ \\
\hline$(\text { Centrality })^{2}$ & & $-4.933^{* *}(1.877)$ & $-4.897^{* *}(1.879)$ & $-4.579^{* *}(1.852)$ & & $-2.509^{*}(1.244)$ & $-2.542^{*}(1.245)$ & $-7.829^{*}(3.689)$ \\
\hline $\begin{array}{l}\text { Industry } \\
\text { experience }\end{array}$ & & & $.023(.069)$ & $-.023(.108)$ & & & $.039(.050)$ & $.101(.081)$ \\
\hline $\begin{array}{l}\text { Centrality }{ }^{*} \\
\text { Ind. exp. }\end{array}$ & & & & $.362(1.075)$ & & & & $-1.061^{\dagger}(.463)$ \\
\hline $\begin{array}{l}(\text { Centrality })^{2} * \\
\text { Ind. exp. }\end{array}$ & & & & $-.112(1.925)$ & & & & $1.743^{*}(.644)$ \\
\hline \multicolumn{9}{|l|}{ Controls } \\
\hline $\begin{array}{l}\text { No of US } \\
\text { (Chinese) } \\
\text { partners }\end{array}$ & $.013(.040)$ & $.002(.040)$ & $.002(.040)$ & $.003(.041)$ & $.201^{\dagger}(.112)$ & $.051(.089)$ & $.052(.089)$ & $.051(.089)$ \\
\hline Round & $.114^{*}(.051)$ & $.115^{*}(.052)$ & $.114^{*}(.052)$ & $.113^{*}(.052)$ & $.331^{* * *}(.041)$ & $.336^{* * *}(.041)$ & $.334^{* * *}(.041)$ & $.335^{* * *}(.041)$ \\
\hline Ln(Venture age) & $-.143^{\dagger}(.083)$ & $-.148^{\dagger}(.083)$ & $-.148^{\dagger}(.083)$ & $-.144^{\dagger}(.084)$ & $-.163^{*}(.067)$ & $-.156^{*}(.067)$ & $-.156^{*}(.067)$ & $-.156^{*}(.067)$ \\
\hline $\begin{array}{l}\text { Information } \\
\text { technology }\end{array}$ & $.334^{\dagger}(.172)$ & $.291^{\dagger}(.173)$ & $.298^{\dagger}(.174)$ & $.307^{\dagger}(.175)$ & $.981^{* * *}(.143)$ & $.967^{* * *}(.144)$ & $.977^{* * *}(.145)$ & $.987^{* * *}(.145)$ \\
\hline Medical & $.403(.276)$ & .339 (.279) & $.341(.279)$ & $.354(.280)$ & $.686^{* *}(.255)$ & $.663^{* *}(.257)$ & $.667^{* *}(.257)$ & $.672^{* *}(.257)$ \\
\hline Beijing & $-.032(.170)$ & $-.036(.170)$ & $-.036(.170)$ & $-.037(.170)$ & $.264^{\dagger}(.150)$ & $.270^{\dagger}(.150)$ & $.272^{\dagger}(.150)$ & $.269^{\dagger}(.151)$ \\
\hline Shanghai & $-.090(.191)$ & $-.094(.192)$ & $-.089(.192)$ & $-.091(.192)$ & $.543^{* *}(.161)$ & $.519^{* * *}(.161)$ & $.523^{* *}(.161)$ & $.525^{* *}(.161)$ \\
\hline Shenzhen & $.099(.339)$ & $.146(.340)$ & $.142(.341)$ & $.137(.342)$ & $-.385(.341)$ & $-.370(.340)$ & $-.377(.341)$ & $-.350(.342)$ \\
\hline Early stage & $-.361(.279)$ & $-.419(.281)$ & $-.417(.281)$ & $-.417(.281)$ & $-.670^{* * *}(.273)$ & $-.707^{* * *}(.274)$ & $-.702^{* * *}(.274)$ & $-.714^{* *}(.274)$ \\
\hline Startup & $-.306(.380)$ & $-.273(.382)$ & $-.265(.382)$ & $-.259(.383)$ & $.137(.302)$ & $.164(.302)$ & $.185(.304)$ & $.179(.304)$ \\
\hline VC stage & $.141(.201)$ & $.155(.211)$ & $.157(.212)$ & $.165(.212)$ & $-.143(.180)$ & $-.123(.181)$ & $-.121(.181)$ & $-.139(.181)$ \\
\hline Constant & $-1.105^{* * *}(.347)$ & $-1.279^{* * *}(.310)$ & $-1.347^{* * *}(.374)$ & $-1.242^{* *}(.425)$ & $-2.459^{* * * *}(.287)$ & $-2.563^{* * *}(.291)$ & $-2.689^{* * *}(.332)$ & $-2.857^{* * *}(.370)$ \\
\hline Year dummies & Included & Included & Included & Included & Included & Included & Included & Included \\
\hline LR Chi ${ }^{2}$ & $76.090^{* * *}$ & $84.668^{* * *}$ & $84.773^{* * *}$ & $85.216^{* * *}$ & $448.671^{* * *}$ & $452.978^{* * *}$ & $453.590^{* * *}$ & $459.926^{* * *}$ \\
\hline$\Delta$ LR $\mathrm{Chi}^{2}$ & & $8.578^{* *}$ & & .443 & & $4.307^{*}$ & & $6.336^{*}$ \\
\hline $\begin{array}{l}\text { Dispersion } \\
\text { parameter } \\
\text { alpha }\end{array}$ & $1.79 \mathrm{e}-07(.0001)$ & $4.30 \mathrm{e}-07(.0002)$ & $3.21 \mathrm{e}-07(.0002)$ & $6.29 \mathrm{e}-08(.00003)$ & $.749(.092)$ & $.717(.091)$ & $.588(.083)$ & $.586(.083)$ \\
\hline $\begin{array}{l}\text { LR test of } \\
\text { alpha }=0\end{array}$ & $p=.500$ & $p=.500$ & $p=.500$ & $p=.498$ & $p=.000$ & $p=.000$ & $p=.000$ & $p=.000$ \\
\hline
\end{tabular}

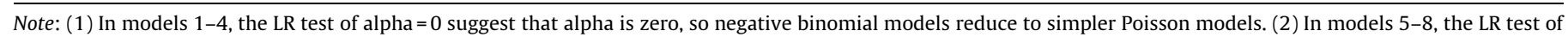
alpha $=0$ shows that alpha is greater than zero, so negative binomial models are better than Poisson models. (3).

${ }^{\dagger} p<0.1$.

${ }^{*} p<0.05$.

${ }^{* *} p<0.01$.

$p<0.001$. 


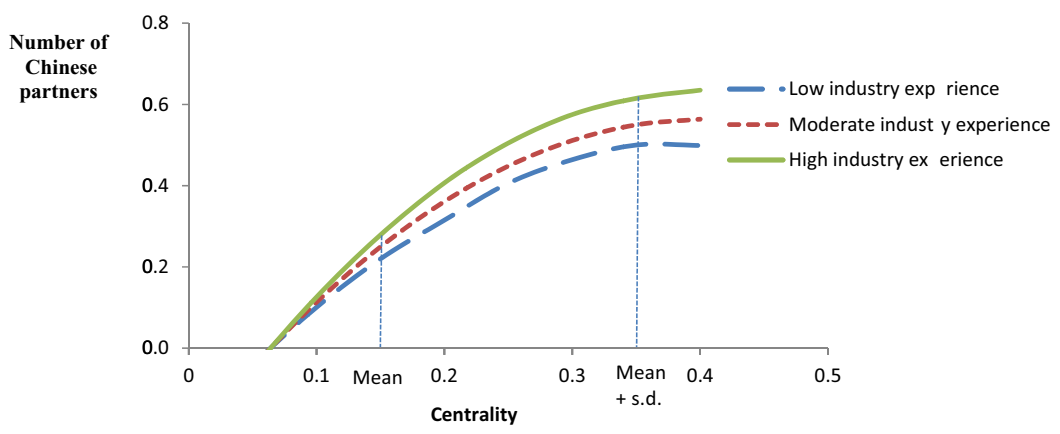

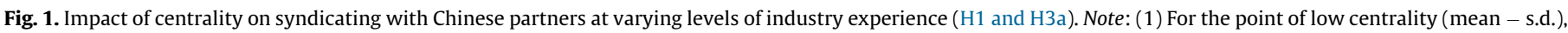

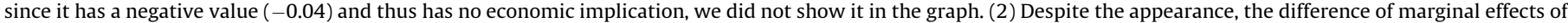
centrality between the three curves is not statistically significant. So, H3a is not supported.

deviation below and above the mean value. Note that during the range of centrality the relationship between centrality and number of Chinese (US) partners mostly appears as the left side of an inverted U-shaped curve before the inflection point. Moreover, the curve is flatter when industry experience is higher in Fig. 2, while the slopes of the curves are insignificantly different in Fig. 1. These findings suggest that $\mathrm{H} 3 \mathrm{~b}$ is supported, while $\mathrm{H} 3 \mathrm{a}$ is not.

\subsection{Robustness tests}

We conducted various robustness tests. Above all, we added the control variable "network centrality in the US" to account for focal US VC firms' overseas reputation effects. Prior studies have suggested that reputation is transferable across borders (Guler \& Guillén, 2010). The variable was calculated using the same method as the independent variable (i.e., network centrality in China), except that all deals were based on the US market. The correlation between the network centrality in the United States and in China is 0.839 , which strongly supports the view of reputation transfer (Guler \& Guillén, 2010). The regression results remain supportive for all hypotheses except for relatively lower levels of significance for the variables of interest. This suggests that our results are conservative and robust. Given the extremely high level of collinearity, we did not include this control in our final models.

In addition, we excluded deals in the expansion stage and the results remained. We also replaced dummies of the three cities with the dummy "whether located in one of the three major cities" and replaced "the number of US (Chinese) partners" with "whether at least one US (Chinese) partner is present in the deal", but did not find changed results. All of these suggest that our results are robust to a satisfactory level.

\section{Additional analyses}

When developing Hypotheses 1 and 2, we argued that after reaching a certain level of centrality, US VC firms will invest alone or with fewer but high-status partners. To further examine this argument, we conducted additional analysis to check whether the status of partners rises along with increases in focal firms' centrality. We used the average value of centralities of all Chinese (US) partners in a syndicate to measure the status level of the Chinese (US) partners (the dependent variable) and kept all independent and control variables. Table 3 shows the results. We found a positive relationship between focal US VC firms' centrality and their Chinese partners' status level (in Model 2, the coefficient of "centrality" is significantly positive $(b=0.141, p<0.05)$, and insignificant for "centrality" ${ }^{2}$, and the same result was found for their US partners (in Model 4, the coefficient of "centrality" is significantly positive $(b=0.187, p<0.01)$, and insignificant for "centrality ${ }^{2 ")}$. The results offer strong support for our argument that highly central US VC firms syndicate with high-status partners.

The results of testing Hypotheses 3a and 3b show that industry experience is an effective remedy for the US VC firms' low centrality when they syndicate with other US partners, but not with Chinese partners. Then one question arises: why does industry experience impact two groups of partners differently? We believe that the main reason lies in the different levels of information about the focal US VC firms possessed by the partners and consequently the different levels of trust on them (Gulati, 1995). Since prospective US partners have been operating in the United States, they have plenty of information about the focal US VC firms. Even though the focal US VC firms with rich industry

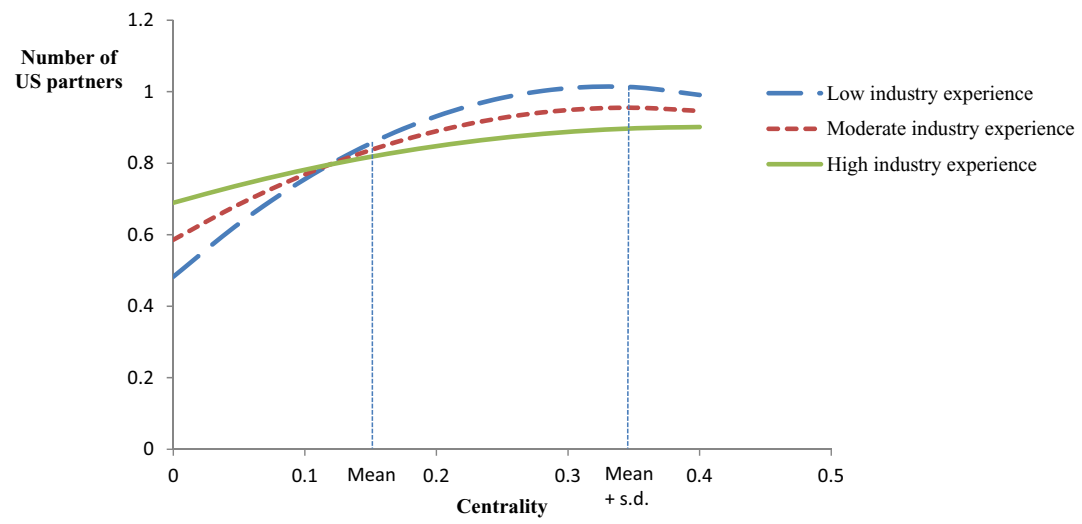

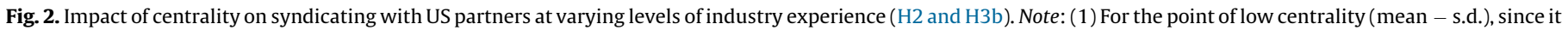

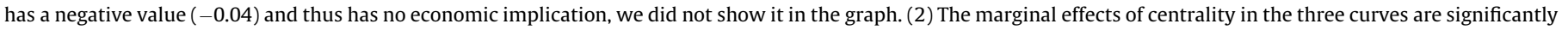
different, so H3b is supported. 
Table 3

OLS regressions predicting the average centrality of Chinese (US) partners ( $n=1213$ ) (additional analysis).

\begin{tabular}{|c|c|c|c|c|}
\hline & \multicolumn{2}{|c|}{ DV: Average centrality of Chinese partners } & \multicolumn{2}{|c|}{ DV: Average centrality of US partners } \\
\hline & Model 1 & Model 2 & Model 3 & Model 4 \\
\hline \multicolumn{5}{|l|}{ Predictors } \\
\hline Centrality & & $.141^{*}(.057)$ & & $.187^{* *}(.061)$ \\
\hline$(\text { Centrality })^{2}$ & & $-.143(.091)$ & & $-.159(.097)$ \\
\hline \multicolumn{5}{|l|}{ Controls } \\
\hline No of US (Chinese) partners & $.015^{* * *}(.003)$ & $.014^{* * *}(.003)$ & $.008(.007)$ & $.006(.007)$ \\
\hline Round & $.004(.003)$ & $.003(.003)$ & $.008^{*}(.003)$ & $.007^{*}(.003)$ \\
\hline Ln(Venture age) & $.004(.005)$ & $.004(.005)$ & $-.011^{*}(.005)$ & $-.010^{*}(.005)$ \\
\hline Information Technology & $.031^{* *}(.010)$ & $.028^{* *}(.010)$ & $.030^{*}(.010)$ & $.024^{*}(.010)$ \\
\hline Medical & $-.007(.017)$ & $-.011(.017)$ & $.004(.018)$ & $-.002(.018)$ \\
\hline Beijing & $-.015(.010)$ & $-.015(.010)$ & $.008(.011)$ & $.008(.011)$ \\
\hline Shanghai & $-.025^{*}(.011)$ & $-.024^{*}(.011)$ & $.018(.012)$ & $.018(.012)$ \\
\hline Shenzhen & $-.007(.020)$ & $-.007(.020)$ & $-.015(.022)$ & $-.015(.021)$ \\
\hline Early stage & $.013(.016)$ & $.010(.016)$ & $-.016(.018)$ & $-.021(.018)$ \\
\hline Startup & $.034(.023)$ & $.035(.023)$ & $-.034(.025)$ & $-.032(.025)$ \\
\hline VC stage & $.027^{*}(.012)$ & $.028^{*}(.012)$ & $.002(.013)$ & $.002(.013)$ \\
\hline Constant & $.017(.019)$ & $-.044(.033)$ & $.014(.020)$ & $.035(.035)$ \\
\hline Year dummies & Included & Included & Included & Included \\
\hline Adjusted $R^{2}$ & .097 & 0.103 & .074 & 0.09 \\
\hline$F$ & 6.404 & 6.374 & 5.056 & 5.624 \\
\hline Sig & .000 & .000 & .000 & .000 \\
\hline
\end{tabular}

experience are new to the Chinese market and thus have a low centrality, their existing reputation in the United States will still make them ideal partners for the other US VC firms. In contrast, Chinese VC firms do not have enough information about the foreign firms (i.e., the US VC firms), in particular if the latter is new to China. In addition, in collectivist culture of China, firms put a heavy weight on personal relationships (i.e., guanxi) to sustain trust and form inter-firm links (Özer, Zheng, \& Ren, 2014). As such, Chinese VC firms will mainly resort to the US VC firms' Chinese network position when judging their quality and trustworthiness. Therefore, industry experience, which is mostly accumulated in the United States, does not function as an effective remedy for their low-centrality when US VC firms are new to China.

To verify this logic, we propose that host country experience, which is accumulated in China and thus easily accessed and valued by Chinese partners, may weaken the impact of centrality on syndication when US VC firms syndicate with Chinese partners. Note that host country experience is distinguished from network centrality in the host country. Foreign firms could gain host country experience through stand-alone operations, or their network lacks well-connected partners so their centrality is still low. We measured host country experience by the natural logarithm of the accumulated number of deals that the focal firm has made in China prior to the particular deal (Meuleman et al., 2009), and kept all independent and control variables. Again, Poisson regressions were applied to test this proposition, because the LR tests suggested that the dispersion parameter alpha equaled zero, which means that Negative binomial models reduced to Poisson models. Table 4 shows the results. In model 4 , the coefficient for "(centrality) ${ }^{*}$ host country experience" is $5.578(p<0.05)$, and the coefficient for "centrality * host country experience" is $-1.744(p<0.10)$. To visualize the non-linear interaction effect, we plotted the result in Fig. 3. The figure shows that for the curve representing firms with richer host country experience its left-side slop is flatter compared to that of other curves. This lends support to our proposition.

\section{Discussion}

\subsection{Contributions}

This study makes three theoretical and empirical contributions. First, theoretically, this study responds to the calls for more studies integrating social network theory and RDT to better explain different dynamics in alliances (Gulati, 1995; Hillman et al., 2009). We contribute to this stream of research by introducing network centrality as an important factor that influences firms' interdependence, and thus attractiveness and willingness to form alliances. Our findings show that up to a certain level of centrality in the Chinese syndication network, US VC firms are willing to syndicate with both Chinese and other US VC firms. However, after reaching that point, as centrality continues to increase, the number of partners (both US and Chinese) in their syndicates decreases. Our additional analysis suggests that US VC firms with high centrality tend to partner with firms with high centrality, which supports the notion that high-status firms are more likely to attract and favor other firms with high status (Guler \& Guillén, 2010; Sorenson \& Stuart, 2008). Overall, our findings suggest that paradoxically constant improvement in network centrality by allying with others will eventually reduce dependence on other firms. Integrating RDT with social network theory, this study contributes to the literature by providing a better understanding of how network structure (i.e., firms' position in their egocentric network) impacts the web of interdependency and consequently formation of inter-firm links.

Second, this study examines an understudied topic on alliances between firms from the same home country and compares alliance behavior between foreign-foreign and foreign-local partnerships. Our study suggests that having a partner from home country is a plausible strategy to reduce the environmental uncertainty and mitigate the LOF. Moreover, our findings confirm that for foreign firms new to a host country, their industry experience can partially compensate for the lack of attractiveness due to a low network centrality in the host country. But the moderating effect only functions when the foreign firms pursue home-country partners, 
Table 4

Poisson regressions predicting the number of Chinese partners $(n=1213)$ (additional analysis).

\begin{tabular}{|c|c|c|c|c|}
\hline & Model 1 & Model 2 & Model 3 & Model 4 \\
\hline \multicolumn{5}{|l|}{ Predictors } \\
\hline Centrality & & $3.056^{* *}(1.062)$ & $4.916^{* * *}(1.189)$ & $10.076^{* * *}(3.062)$ \\
\hline$(\text { Centrality })^{2}$ & & $-4.933^{* *}(1.877)$ & $-6.654^{* * *}(1.947)$ & $-23.232^{* * * *}(7.004)$ \\
\hline Host country experience & & & $-.233^{* * * *}(.064)$ & $-.250^{* *}(.080)$ \\
\hline Centrality ${ }^{*}$ Host count. exp. & & & & $-1.744^{\dagger}(1.059)$ \\
\hline$(\text { Centrality })^{2}{ }^{*}$ Host count. exp. & & & & $5.578^{*}(2.294)$ \\
\hline \multicolumn{5}{|l|}{ Controls } \\
\hline No of U.S. partners & $.013(.040)$ & $.002(.040)$ & $-.030(.042)$ & $-.034(.042)$ \\
\hline Round & $.114(.051)$ & $.115^{*}(.052)$ & $.129^{*}(.052)$ & $.132^{*}(.052)$ \\
\hline Ln(Venture age) & $-.143^{\dagger}(.083)$ & $-.148^{\dagger}(.083)$ & $-.126(.084)$ & $-.106(.085)$ \\
\hline Information Technology & $.334^{\dagger}(.172)$ & $.291^{\dagger}(.173)$ & $.255(.175)$ & $.226(.176)$ \\
\hline Medical & $.403(.276)$ & $.339(.279)$ & $.328(.279)$ & $.357(.281)$ \\
\hline Beijing & $-.032(.170)$ & $-.036(.170)$ & $-.069(.171)$ & $-.090(.171)$ \\
\hline Shanghai & $-.090(.191)$ & $-.094(.192)$ & $-.126(.193)$ & $-.168^{\dagger}(.195)$ \\
\hline Shenzhen & $.099(.339)$ & $.146(.340)$ & $.127(.341)$ & $.032(.343)$ \\
\hline Early stage & $-.361(.279)$ & $-.419(.281)$ & $-.406(.282)$ & $-.377(.284)$ \\
\hline Startup & $-.306(.380)$ & $-.273(.382)$ & $-.238(.382)$ & $-.164(.386)$ \\
\hline VC stage & $.141(.210)$ & $.155(.211)$ & $.146(.213)$ & $.148(.214)$ \\
\hline Constant & $-1.105^{* * *}(.347)$ & $-1.279^{* * * *}(.310)$ & $-.782^{*}(.338)$ & $-.764^{*}(.346)$ \\
\hline Year dummies & Included & Included & Included & Included \\
\hline LR Chi ${ }^{2}$ & $76.090^{* * *}$ & $84.668^{* * *}$ & $98.369^{* * *}$ & $110.629^{* * *}$ \\
\hline$\Delta \mathrm{LR} \mathrm{Chi}^{2}$ & & & & $12.26^{* *}$ \\
\hline $\begin{array}{l}p<0.1 \\
p<0.05 \\
*_{* * *}^{\dagger} p<0.01 \\
p<0.001\end{array}$ & & & & \\
\hline
\end{tabular}

but not local partners; to pursue local partners, they must have rich experience in the host country. Theoretically, the findings of the different moderating effects indicate the geographic constraints of information flow in international alliances. While home-country partners may be familiar with the information about foreign firms' industry experience, which is expected to be mostly accumulated in the home country, it is difficult for local firms to collect, evaluate, and rely on such information; in contrast, local firms tend to more heavily rely on the information conveyed in the local business networks, which is particularly prominent in a collectivist culture, such as Chinese culture (Özer et al., 2014). Another interesting finding is that the two variables "number of Chinese partners" and "number of US partners" have a very weak and positive relationship, if any, as indicated by Tables 2 and 3. It suggests that having US partners cannot substitute for Chinese partners, and the two groups of partners may deliver different values to focal US VC firms. In sum, our findings on the similarities, dissimilarities, and relationship between foreign-foreign and foreign-local partnerships offer initial important insights on the topic. Further studies in this direction are greatly warranted and deemed fruitful.
Finally, this study sheds new light on the research of crossborder VC syndication; in particular, it offers fresh information on the syndication activities of the US VC firms (the pioneer and the largest VC funds exporter) in the Chinese market (the largest VC fund importer). One interesting finding is that on average US VC firms syndicate with more US than Chinese partners (as shown in Table 1, the mean value of "the number of US partners" is 0.83 , while "the number of Chinese partners" is 0.28 ). This finding demonstrates the importance of our analysis on the foreign-foreign alliances in this study. Theoretically, it calls for more in-depth analysis on the information and trust concerns in syndication formation when the host and home countries are significantly different in cultural and institutional environment.

\subsection{Managerial implications}

This study bears some important implications for business practitioners. For foreign firms, our results suggest that it can be very difficult to find partners from either host or home country if they do not have established network connections before entering

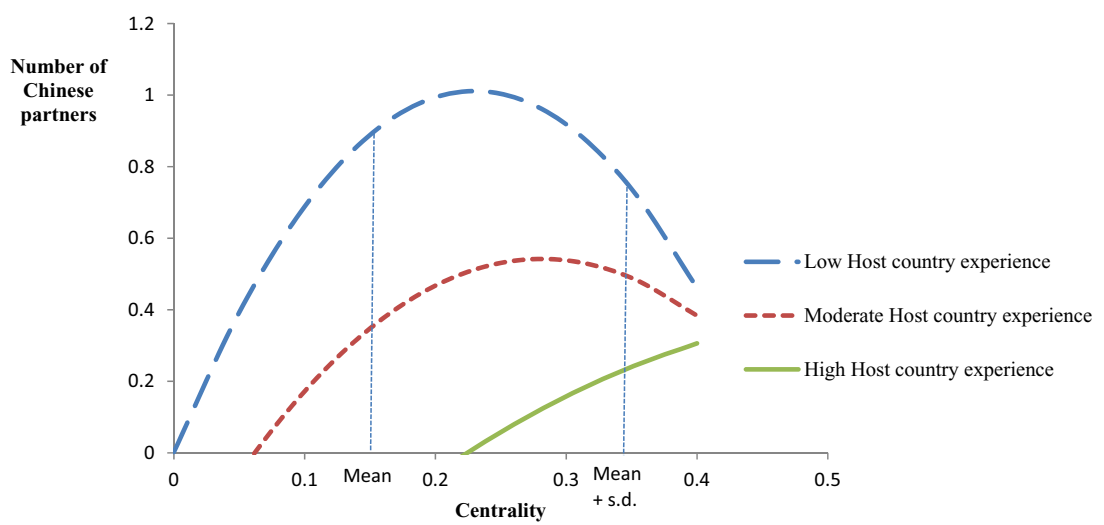

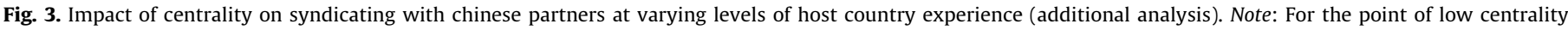
(mean - s.d.), since it has a negative value $(-0.04)$ and thus has no economic implication, we did not show it in the graph. 
the host country. Our findings confirm that industry experience makes foreign firms more attractive to their home country counterparts and reduce initial barriers to form alliances. This suggests that accumulating more experience in home may make the international expansion smoother. Foreign firms may also seek alternatives to building initial networks, such as using their extant home country network ties with firms that have already entered the particular host country (Guller \& Guillén, 2010). As to partnering with local firms, our additional analysis shows that host country experience (even if it has not resulted in a central position) makes foreign firms more attractive and trustworthy to local firms and enhances the likelihood of syndication among them. In other words, foreign firms' presence in the host country creates the opportunity for local firms to develop trust with them (Lu \& Hwang, 2010), and increases the syndication likelihood.

For host country firms, this study suggests that solely providing knowledge and information about the local market cannot guarantee a long-term relationship with foreign firms. Foreign firms may establish inter-firm relationship with local peers initially; however, after they learn how to operate in the host country their desire to syndicate with local firms will decrease. Therefore, to maintain long-term relationships with foreign firms, local firms should provide more value in alliances. In our context, Chinese VC firms could actively participate in post-investment activities that are beyond the competencies of their foreign partners. For instance, they may assist ventures in obtaining suppliers or customers in other Chinese cities (Brander et al., 2002; Dai et al., 2012; Wright et al., 2005). They can also expand foreign partners' investments opportunities by connecting them to different regional markets. In addition, our finding that firms with a more central position are more likely to partner with high-status firms suggests that establishing an extensive network and achieving a prominent position in the domestic market will be a valuable investment for host country firms. Partnering with highstatus firms from developed countries is a precious learning experience for local firms. It also expands the local firms' investment horizon to other countries.

\subsection{Limitations and future research directions}

Although we believe that this research contributes to the international alliance literature, it is not without limitations. First, our study is focused on US VC firms investing in China. We chose these firms mainly because they represent the firms from developed countries entering emerging economies, for which using alliances is the dominant strategy. Although past studies have shown high degrees of similarity among VC firms in some developed economies such as the United States and United Kingdom (Wright et al., 2005), other developed countries such as France, Germany, and Japan have VC industries with different characteristics in terms of management style and organizational form (Jeng \& Wells, 2000). Similarly, while emerging economies share some common characteristics in their VC industries, such as high risks and weak legal protection, they also have idiosyncratic characteristics (Ahlstrom et al., 2007; Bruton, Dattani, Fung, Chow, \& Ahlstrom, 1999). Therefore, we should exercise caution in generalizing the findings to other contexts. Future research can enhance the generalizability of our findings by examining international alliance behavior of firms from other countries to capture any market-specific factors that influence the patterns presented in this research (Doh, 2015).

Second, although this study suggests the importance of a central position in the host country, network position was only examined as an extant condition. Future research could investigate how a foreign firm reaches such a central position. For instance, some US VC managers were born in China and received higher education in the United States before they worked for US VC firms. Therefore, it is interesting to examine whether and how individual level variables, such as US VC managers' personal connections and experience in China, explain their firms' networks established in early years.

Finally, we selected the VC industry as our research context because of the importance of networks in this industry and the general similarities between syndicates in this industry and alliances in other industries (Guller \& Guillén, 2010). However, syndicates are to some extent different from alliances (Wright \& Lockett, 2003). First, unlike traditional alliances, VC firms do not engage in day-to-day operation of the invested ventures but mostly play a supportive and monitoring role. Moreover, the ultimate goal of VC firms is to exit the ventures in the form of an initial public offering or a merger or acquisition rather than long term ownership. These features perhaps influence the patterns of international alliance formation identified in this study. Future studies could examine other industries to check the robustness of our findings.

\section{Conclusion}

What determines foreign firms' alliance formation in the host country? Our answer is (1) that current position in the host country business network is one of the determinants of future alliance behavior, and (2) that the effect is moderated by the foreign firms' industry experience. Our theoretical framework shows that network position not only influences partners' dependence on foreign firms, but also foreign firms' dependence on partners, and such effect can be leveraged by factors exogenous to the host country network. In conclusion, the most important message of this study is that the integration of resource dependence theory and social network theory can increase our understanding of alliance formation significantly.

\section{References}

Abell, P., \& Nisar, T. M. (2007). Performance effects of venture capital firm networks. Management Decision, 45: 923-936.

Ahlstrom, D., \& Bruton, G. D. (2006). Venture capital in emerging economies: Networks and institutional change. Entrepreneurship Theory and Practice, 30(2): 299-320.

Ahlstrom, D., Bruton, G. D., \& Yeh, K. S. (2007). Venture capital in China: Past, present, and future. Asia Pacific Journal of Management, 24: 247-268.

Ahlstrom, D., Levitas, E., Hitt, M. A., Dacin, M. T., \& Zhu, H. (2014). The three faces of China: Strategic alliance partner selection in three ethnic Chinese economies. Journal of World Business, 49(4): 572-585.

Ahlstrom, D., Young, M. N., Nair, A., \& Law, P. (2003). Managing the institutional environment: Challenges for foreign firms in post-WTO China. SAM Advanced Management Journal, 68(1): 41-49.

Ahuja, G. (2000). The duality of collaboration: Inducements and opportunities in the formation of interfirm linkages. Strategic Management Journal, 21: 317-343.

Aiken, L. S., \& West, S. G. (1991). Multiple regression. Beverly Hills: Sage Publishing.

Bae, J., \& Insead, M. G. (2004). Partner substitutability, alliance network structure, and firm profitability in the telecommunications industry. Academy of Management Journal, 47(6): 843-859.

Barringer, B. R., \& Harrison, J. S. (2000). Walking a tightrope: Creating value through interorganizational relationships. Journal of Management, 26(3): 367-403.

Barry, C. B. (1994). New directions in research on venture capital finance. Financial Management, 23(3): 3-15.

Barry, C. B., Muscarella, C. J., Peavy, J. W., III, \& Vetsuypens, M. R. (1990). The role of venture capital in the creation of public companies: Evidence from the goingpublic process. Journal of Financial Economics, 27: 447-471.

Batjargal, B. (2007). Network triads: Transitivity, referral and venture capital decisions in China and Russia. Journal of International Business Studies, 38: 998-1012.

Baum, J. A. C., Calabrese, T., \& Silverman, B. S. (2000). Don't go it alone: Alliance network composition and startups' performance in Canadian biotechnology. Strategic Management Journal, 21: 267-294.

Baum, J. A. C., \& Oliver, C. (1991). Institutional linkages and organizational mortality. Administrative Science Quarterly, 36: 187-218.

Beckman, C. M., Haunschild, P. R., \& Phillips, D. J. (2004). Friends or strangers? Firm-specific uncertainty, market uncertainty, and network partner selection. Organization Science, 15(3): 259-275.

Bell, R. G., Filatotchev, I., \& Rasheed, A. A. (2012). The liability of foreignness in capital markets: Sources and remedies. Journal of International Business Studies, 43(2): 107-122. 
Benjamin, B. A., \& Podolny, J. M. (1999). Status, quality, and social order in the California wine industry. Administrative Science Quarterly, 44(3): 563-589.

Black, B. S., \& Gilson, R. J. (1998). Venture capital and structure of capital markets: Bank versus stock markets. Journal of Financial Economics, 47: 243-277.

Bonacich, P. (1987). Power and centrality: A family of measures. American Journal of Sociology, 92: 1170-1182.

Brander, J. A., Amit, R., \& Antweiler, W. (2002). Venture-capital syndication: Improved venture selection vs. the value-added hypothesis. Journal of Economics \& Management Strategy, 11: 423-452.

Bruton, G., \& Ahlstrom, D. (2003). An institutional view of China's venture capital industry: Explaining the differences between China and the West. Journal of Business Venturing, 18: 233-259.

Bruton, G., Ahlstrom, D., \& Yeh, K. S. (2004). Understanding venture capital in East Asia: The impact of institutions on the industry today and tomorrow. Journal of World Business, 39(1): 72-88.

Bruton, G. D., Dattani, M., Fung, M., Chow, C., \& Ahlstrom, D. (1999). Private equity in China: Differences and similarities with the Western model. Journal of Private Equity, 1: 7-13.

Cameron, A. C., \& Trivedi, P. K. (1998). Regression analysis of count data. Cambridge: Cambridge University Press.

Casamatta, C., \& Haritchabalet, C. (2007). Experience, screening and syndication in venture capital investments. Journal of Financial Intermediation, 16(3): 368-398.

Casciaro, T., \& Piskorski, M. J. (2005). Power imbalance, mutual dependence, and constraint absorption: A closer look at resource dependence theory. Administrative Science Quarterly, 50(2): 167-199.

Castilla, E. J. (2005). Social networks, location, and investment performance: A study of venture-capital funded start-up companies over time. Cambridge, MA: Working paper Massachusetts Institute of Technology.

Chao, M. C. H., \& Kumar, V. (2010). The impact of institutional distance on the international diversity-performance relationship. Journal of World Business, 45(1): 93-103.

Chemmanur, T., Hull, T., \& Krishnan, K. (2012). Do local and international venture capitalists play well together? A study of international venture capital investments Chicago, IL: Paper presented at the annual meeting of the American Finance Association.

Chen, H., \& Chen, T. J. (2003). Governance structures in strategic alliances: Transaction cost versus resource-based perspective. Journal of World Business, 38(1): $1-14$

Contractor, F. J., \& Woodley, J. A. (2015). How the valliance pie is split: Value appropriation by each partner in cross-border technology transfer alliances. Journal of World Business, 50(3): 535-547.

Dacin, M. T., Hitt, M. A., \& Levitas, E. (1997). Selecting partners for successful international alliances: Examination of US and Korea firms. Journal of World Business, 32: 3-16.

Dacin, M. T., Oliver, C., \& Roy, J. P. (2007). The legitimacy of strategic alliances: An institutional perspective. Strategic Management Journal, 28(2): 169-187.

Dai, N., Jo, H., \& Kassicieh, S. (2012). Cross-border venture capital investments in Asia: Selection and exit performance. Journal of Business Venturing, 27: 666-684.

Damanpour, F., Devece, C., Chen, C. C., \& Pothukuchi, V. (2012). Organizational culture and partner interaction in the management of international joint ventures in India. Asia Pacific Journal of Management, 28(2): 169-187.

Das, T. K., \& Teng, B. S. (2001). Trust, control, and risk in strategic alliances: An integrated framework. Organization Studies, 22(2): 251-283.

De Clercq, D., \& Dimov, D. (2004). Explaining venture capital firms' syndication behaviour: A longitudinal study. Venture Capital: An International Journal of Entrepreneurial Finance, 6(4): 243-256.

Dimov, D., \& De Clercq, D. (2006). Venture capital investment strategy and portfolio failure rate: A longitudinal study. Entrepreneurship Theory and Practice, 30(2): 207-223.

Doh, J. P. (2015). From the Editor: Why we need phenomenon-based research in international business. Journal of World Business, 50(4): 609-611.

Dong, L., \& Glaister, K. W. (2006). Motives and partner selection criteria in international strategic alliances: Perspectives of Chinese firms. International Business Review, 15: 577-600.

Drees, J. M., \& Heugens, P. P. (2013). Synthesizing and extending resource dependence theory: A meta-analysis. Journal of Management. http://dx.doi.org/ 10.1177/0149206312471391

Eisenhardt, K. M., \& Schoonhoven, C. B. (1996). Resource based view of strategic alliance formation: Strategic and social effects in entrepreneurial firms. Organizational Science, 7: 136-150.

Fernald, J., \& Babson, O. (1999). Why has China survived the Asian crisis so well? What risks remain?. In FRB International Finance Discussion Paper No. 633 Available at SSRN: http://ssrn.com/abstract=154629 or http://dx.doi.org/10. 2139/ssrn.154629

Florida, R. L., \& Kenney, M. (1988). Venture capital-financed innovation and technological change in the USA. Research Policy, 17(3): 119-137.

Giddens, A. (1984). The constitution of society: Outline of the theory of structuration. Berkeley: University of California Press.

Gifford, S. (1997). Limited attention and the role of the venture capitalist. Journal of Business Venturing, 12(6): 459-482.

Gillespie, K., \& Teegen, H. (1995). Market liberalization and international alliance formation: The Mexican paradigm. Columbia Journal of World Business, 30: 58-69.

Gilson, R. J. (2003). Engineering a venture capital market: Lessons from the American experience. Stanford Law Review, 55: 1067-1103.

Glaeser, E. L., Laibson, D., Scheinkman, J. A., \& Soutter, C. L. (2000). Measuring trust. Quarterly Journal of Economics, 65: 811-846.
Gompers, P., \& Lerner, J. (1996). The use of covenants: An empirical analysis of venture partnership agreements. Journal of Law and Economics, 39(2): 463-498.

Gompers, P., \& Lerner, J. (2000). The venture capital cycle. Cambridge, MA: MIT Press.

Gompers, P., \& Lerner, J. (2001). The money of invention: How venture capital creates wealth. Boston, MA: Harvard Business School Press.

Gompers, P., Kovner, A., Lerner, J., \& Scharfstein, D. (2010). Performance persistence in entrepreneurship. Journal of Financial Economics, 96(1): 18-32.

Gulati, R. (1995). Social structure and alliance formation patterns: A longitudinal analysis. Administrative Science Quarterly, 40(4): 619-652.

Gulati, R., \& Singh, H. (1998). The architecture of cooperation: Managing coordination costs and appropriation concerns in strategic alliances. Administrative Science Quarterly, 43(4): 781-814.

Gulati, R., Nohria, N., \& Zaheer, A. (2000). Strategic networks. Strategic Management Journal, 21(3): 203-215.

Guler, I., \& Guillén, M. F. (2010). Home country networks and foreign expansion: Evidence from the venture capital industry. Academy of Management Journal, 53: 390-410.

Guler, I., \& McGahan, A. (2007). The more the merrier? Institutions and syndication size in international venture capital investments Working paper University of Toronto Rotman School.

Harrigan, K. R., \& Newman, W. H. (1990). Bases of interorganization co-operation: Propensity, power, persistence. Journal of Management Studies, 27(4): 417-434

Heide, J. B. (1994). Interorganizational governance in marketing channels. Journal of Marketing, 58(1): 71-85.

Higgins, M. C., \& Gulati, R. (2003). Getting off to a good start: The effects of upper echelon affiliations on underwriter prestige. Organization Science, 14: 244-263.

Hillman, A. J., Withers, M. C., \& Collins, B. J. (2009). Resource dependence theory: A review. Journal of Management, 35: 1404-1427.

Hitt, M. A., Dacin, M. T., Levitas, E., Arregle, J. L., \& Borza, A. (2000). Partner selection in emerging and developed market contexts: Resource-based and organizational learning perspectives. Academy of Management Journal, 43: 449-467.

Hoang, H., \& Antoncic, B. (2003). Network-based research in entrepreneurship: A critical review. Journal of Business Venturing, 18: 165-187.

Hochberg, Y. V., Ljungqvist, A., \& Lu, Y. (2007). Whom you know matters: Venture capital networks and investment performance. Journal of Finance, 62: 251-301.

Hochberg, Y. V., Ljungqvist, A., \& Lu, Y. (2010). Networking as a barrier to entry and the competitive supply of venture capital. Journal of Finance, 65(3): 829-859.

Hopp, C. (2010). When do venture capitalists collaborate? Evidence on the driving forces of venture capital syndication. Small Business Economics, 35(4): 417-431.

Hopp, C., \& Rieder, F. (2011). What drives venture capital syndication? Applied Economics, 43(23): 3089-3102.

Hursti, J., \& Maula, M. (2007). Acquiring financial resources from foreign equity capital markets: An examination of factors influencing foreign initial public offerings. Journal of Business Venturing, 22(6): 833-851.

Jääskeläinen, M. (2012). Venture capital syndication: Synthesis and future directions. International Journal of Management Reviews, 14(4): 444-463.

Jeng, L. A., \& Wells, P. C. (2000). The determinants of venture capital funding: Evidence across countries. Journal of Corporate Finance, 6: 241-289.

Jensen, M. (2003). The role of network resources in market entry: Commercial banks' entry into investment banking, 1991-1997. Administrative Science Quarterly, 48: 466-497.

Johanson, J., \& Vahlne, J. E. (2009). The Uppsala internationalization process model revisited: From liability of foreignness to liability of outsidership. Journal of International Business Studies, 40(9): 1411-1431.

Johnson, J. L., Cullen, J. B., Sakano, T., \& Takenouchi, H. (1996). Setting the stage for trust and strategic integration in Japanese-US cooperative alliances. Journal of International Business Studies, 27(5): 981-1004.

Kaplan, S., \& Strömberg, P. (2001). Venture capitalists as principals: Contracting, screening, and monitoring. American Economic Review, 91: 426-430.

Kaplan, S. N., \& Strömberg, P. E. (2004). Characteristics, contracts, and actions: Evidence from venture capitalist analyses. Journal of Finance, 59(5): 2177-2210.

Katila, R., Rosenberger, J. D., \& Eisenhardt, K. M. (2008). Swimming with sharks: Technology ventures, defense mechanisms and corporate relationships. Administrative Science Quarterly, 53(2): 295-332.

Keil, T., Maula, M. V., \& Wilson, C. (2010). Unique resources of corporate venture capitalists as a key to entry into rigid venture capital syndication networks. Entrepreneurship Theory and Practice, 34(1): 83-103.

Keister, L. A. (2009). Organizational research on market transition: A sociological approach. Asia Pacific Journal of Management, 26(4): 719-742.

Kotabe, M., Teegen, H., Aulakh, P. S., Coutinho de Arruda, M. C., Santillán-Salgado, R. J. \& Greene, W. (2000). Strategic alliances in emerging Latin America: A view from Brazilian, Chilean, and Mexican companies. Journal of World Business, 35(2): 114-132

Lee, P., \& Wahal, S. (2004). Grandstanding, certification and the underpricing of venture capital backed IPOs. Journal of Financial Economics, 73(2): 375-407.

Lei, D., Slocum, J. W., \& Pitts, R. A. (1997). Building cooperative advantage: Managing strategic alliances to promote organizational learning. Journal of World Business, 32: 203-223.

Lerner, J. (1994a). The syndication of venture capital investments. Journal of the Financial Management Association, 23: 16-27.

Lerner, J. (1994b). Venture capitalists and the decision to go public. Journal of Financial economics, 35(3): 293-316.

Levin, D. Z., \& Barnard, H. (2013). Connections to distant knowledge: Interpersonal ties between more- and less-developed countries. Journal of International Business Studies, 44(7): 676-698. 
Li, S. X., \& Rowley, T. J. (2002). Inertia and evaluation mechanisms in interorganizational partner selection: Syndicate formation among US investment banks. Academy of Management Journal, 45: 1104-1119.

Li, Y., \& Zahra, S. A. (2012). Formal institutions, culture, and venture capital activity: A cross-country analysis. Journal of Business Venturing, 27(1): 95-111.

Long, J. S. (1997). Regression models for categorical and limited dependent variables, Thousand Oaks, CA: Sage.

Lu, J. W., \& Beamish, P. W. (2006). Partnering strategies and performance of SMEs' international joint ventures. Journal of Business Venturing, 21(4): 461-486.

Lu, Q., \& Hwang, P. (2010). The impact of liability of foreignness on international venture capital firms in Singapore. Asia Pacific Journal of Management, 27: 81-97.

Madhok, A. (2006). How much does ownership really matter? Equity and trust relations in joint venture relationships. Journal of International Business Studies, 37(1): 4-11.

Mäkelä, M. M., \& Maula, M. V. (2006). Interorganizational commitment in syndicated cross-border venture capital investments. Entrepreneurship Theory and Practice, 30(2): 273-298.

Manigart, S., Waele, D., Wright, M., Robbie, K., Desbrieres, P., Sapienza, H., et al. (2000). Venture capitalists, investment appraisal and accounting information: A comparative study of the USA, UK, France, Belgium and Holland. European Financial Management, 6(3): 389-403.

Manigart, S., De Waele, K., Wright, M., Robbie, K., Desbrières, P., Sapienza, H. J., et al. (2002). Determinants of required return in venture capital investments: A five-country study. Journal of Business Venturing, 17(4): 291-312.

Manolova, T. S., Manev, I. M., \& Gyoshev, B. S. (2010). In good company: The role of personal and inter-firm networks for new-venture internationalization in a transition economy. Journal of World Business, 45(3): 257-265.

Martí, J., Menéndez-Requejo, S., \& Rottke, O. M. (2013). The impact of venture capital on family businesses: Evidence from Spain. Journal of World Business, 48(3): 420-430

Megginson, W. L., \& Weiss, K. A. (1991). Venture capitalist certification in initial public offerings. Journal of Finance, 46: 879-903.

Meuleman, M., \& Wright, M. (2011). Cross-border private equity syndication: Institutional context and learning. Journal of Business Venturing, 26: 35-48.

Meuleman, M., Wright, M., Manigart, S., \& Lockett, A. (2009). Private equity syndication: Agency costs, reputation and collaboration. Journal of Business Finance \& Accounting, 36(5): 616-644.

Mowery, D., Oxley, J., \& Silverman, B. (1996). Strategic alliances and interfirm knowledge transfer. Strategic Management Journal, 17: 77-91.

Murray, J. Y., Kotabe, M., \& Zhou, J. N. (2005). Strategic alliance-based sourcing and market performance: Evidence from foreign firms operating in China. Journal of International Business Studies, 36(2): 187-208.

Nahata, R. (2008). Venture capital reputation and investment performance. Journal of Financial Economics, 90: 127-151.

Nair, A., Hanvanich, S., \& Cavusgil, S. T. (2007). An exploration of the patterns underlying related and unrelated collaborative ventures using neural network: Empirical investigation of collaborative venture formation data spanning 19852001. International Business Review, 16(6): 659-686.

Nerkar, A., \& Paruchuri, S. (2005). Evolution of R\&D capabilities: The role of knowledge networks within a firm. Management Science, 51: 771-785.

Neter, J., Wasserman, W., \& Kutner, M. H. (1990). Applied statistical models. Homewood, IL: Irwin.

Nielsen, B. B. (2007). Determining international strategic alliance performance: A multidimensional approach. International Business Review, 16(3): 337-361.

O’Brien, J. P., \& David, P. (2014). Reciprocity and R\&D search: Applying the behavioral theory of the firm to a communitarian context. Strategic Management Journal, 35(4): 550-565.

Oliver, C. (1990). Determinants of interorganizational relationships: Integration and future directions. Academy of Management Review, 15(2): 241-265.

Özer, Ö., Zheng, Y., \& Ren, Y. (2014). Trust, trustworthiness, and information sharing in supply chains bridging China and the United States. Management Science, 60(10): 2435-2460.

Ozmel, U., Reuer, J. J., \& Gulati, R. (2012). Signals across multiple networks: How venture capital and alliance networks affect interorganizational collaboration. Academy of Management Journal, 56(3): 852-866.

Park, S. H., Chen, R. R., \& Gallagher, S. (2002). Firm resources as moderators of the relationship between market growth and strategic alliances in semiconductor start-ups. Academy of Management Journal, 45(3): 527-545.

Peng, M. W., Au, K. Y., \& Wang, D. Y. (2001). Interlocking directorates as corporate governance in Third World multinationals: Theory and evidence from Thailand. Asia Pacific Journal of Management, 18(2): 161-181.

Pfeffer, J., \& Salancik, G. (1978). The external control of organizations: A resource dependence perspective. New York: Harper and Row.

Piskorski, M. J., \& Anand, B. (2005). Resources, power, and prestige: Formation of structural inequality in social exchange networks. Working paper Harvard Business School.

Podolny, I. M. (1993). A status-based model of market competition. American Journal of Sociology, 98: 829-872.
Podolny, J. M. (1994). Market uncertainty and the social character of the economic exchange. Administrative Science Quarterly, 39: 458-483.

Podolny, J. M. (2001). Networks as the pipes and prisms of the market. American Journal of Sociology, 107(1): 33-60.

Podolny, J. M. (2005). Status signals: A sociological study of market competition. Princeton, NJ: Princeton University Press.

Pruthi, S., Wright, M., \& Lockett, A. (2003). Do foreign and domestic venture capital firms differ in their monitoring of investees? Asia Pacific Journal of Management, 20: 175-204.

Sahlman, W. A. (1990). The structure and governance of venture-capital organizations. Journal of Financial Economics, 27: 473-521.

Scott, J. (1991). Social network analysis: A handbook. Thousand Oaks, CA: Sage.

Shane, S., \& Stuart, T. (2001). Organizational endowments and performance of university start-ups. Management Science, 48: 154-170.

Shi, W. S., Sun, S. L., Pinkham, B. C., \& Peng, M. W. (2014). Domestic alliance network to attract foreign partners: Evidence from international joint ventures in China. Journal of International Business Studies, 45(3): 338-362.

Sorenson, O., \& Stuart, T. E. (2001). Syndication networks and the spatial distribution of venture capital investments. American Journal of Sociology, 106(6): 1546-1588.

Sorenson, O., \& Stuart, T. E. (2008). Bringing the context back in: Settings and the search for syndicate partners in venture capital investment networks. Administrative Science Quarterly, 53: 266-294.

Sparrowe, R. T., Liden, R. C., Wayne, S. J., \& Kraimer, M. L. (2001). Social networks and the performance of individuals and groups. Academy of Management Journal, 44: 316-325.

Steensma, H. K., Marino, L., Weaver, K. M., \& Dickson, P. H. (2000). The influence of national culture on the formation of technology alliances by entrepreneurial firms. Academy of Management Journal, 43(5): 951-973.

Steier, L., \& Greenwood, R. (1995). Venture capitalist relationships in the deal structuring and post-investment stages of new firm creation. Journal of Management Studies, 32: 337-357.

Stuart, T. E. (2000). Interorganizational alliances and the performance of firms: A study of growth and innovation rates in a high-technology industry. Strategic Management Journal, 21(8): 791-811.

Stuart, T. E., Hoang, H., \& Hybels, R. C. (1999). Interorganizational endorsements and the performance of entrepreneurial ventures. Administrative Science Quarterly, 44: 315-349.

Sun, S. L., Peng, M. W., Lee, R. P., \& Tan, W. (2015). Institutional open access at home and outward internationalization. Journal of World Business, 50(2): 234-246.

Swaminathan, V., \& Moorman, C. (2009). Marketing alliances, firm networks, and firm value creation. Journal of Marketing, 72: 52-69.

Trevino, L. J., \& Mixon, F. G. (2004). Strategic factors affecting foreign direct investment decisions by multinational enterprises in Latin America. Journal of World Business, 39(3): 233-243.

Wang, L., \& Wang, S. (2011). Cross-border venture capital performance: Evidence from China. Pacific-Basin Finance Journal, 19(1): 71-97.

Wang, Y., \& Nicholas, S. (2007). The formation and evolution of non-equity strategic alliances in China. Asia Pacific Journal of Management, 24(2): 131-150.

Wong, L. K., \& Ellis, P. (2002). Social ties and partner identification in Sino-Hong Kong international joint ventures. Journal of International Business Studies, 33(2): 267-289.

Wooldridge, J. M. (2003). Introductory econometrics: A modern approach. Cincinnati, $\mathrm{OH}$ : South-Western College Publishing.

Wright, M., \& Lockett, A. (2003). The structure and management of alliances: Syndication in the venture capital industry. Journal of Management Studies, 40(8): 2073-2102.

Wright, M., Lockett, A., \& Pruthi, S. (2002). Internationalization of western venture capitalists into emerging markets: Risk assessment and information in India. Small Business Economics, 19: 13-29.

Wright, M., Pruthi, S., \& Lockett, A. (2005). International venture capital research: From cross-country comparisons to crossing borders. International Journal of Management Reviews, 7: 135-165.

Wright, M., \& Robbie, K. (1998). Venture capital and private equity: A review and synthesis. Journal of Business Finance and Accounting, 25(5 \& 6): 521-570.

Yan, A., \& Gray, B. (1994). Bargaining power, management control, and performance in United States-China joint ventures: A comparative case study. Academy of Management Journal, 37: 1478-1517.

Yellen, J. L. (2007). The Asian financial crisis ten years later: Assessing the past and looking to the future. Los Angeles, California: Speech to the Asia Society of Southern California.

Young-Ybarra, C., \& Wiersema, M. (1999). Strategic flexibility in information technology alliances: The influence of transaction cost economics and social exchange theory. Organization Science, 10(4): 439-459.

Zaheer, S. (1995). Overcoming the liability of foreignness. Academy of Management Journal, 38: 341-363.

Zero2ipo research (2013). China Private Equity Annual Report. Beijing, China: zero2ipo Co. 